\title{
生体関連機能に関するモデル系の合成と性質——金属間相互作用 及び核酸塩基-芳香族化合物相互作用のモデル化合物
}

\author{
久留正雄 \\ 東京理科大学薬学部, 干162-0826 新宿区市厅谷船河原町 12
}

\section{Synthesis and Characterization of Model System in Biological Related Function - Model Compounds for Investigation of Metal-Metal Interaction and Nucleobase-Aromatics Interaction}

\author{
Masao HisATOME \\ Faculty of Pharmaceutical Sciences, Science University of Tokyo, \\ 12 Ichigaya-Funagawara, Shinjuku-ku, Tokyo 162-0826, Japan
}

(Received April 25, 2001)

\begin{abstract}
Several kinds of compounds available as model systems to investigation on metal-metal interaction in metalloproteins and on interaction of aromatics with nucleobases in arene intercalation to DNA were synthesized and characterized by spectrometry. Double and triple layered porphyrinophanes linked with 1,1'- or 1,3-disubstituted ferrocene moieties and their iron and cobalt complexes were prepared. Stabilities of their oxygenation complexes depended on bridging mode, lengths of alkyl linkers, distance between metals, and feature of hydrophobic cavity. Ferrocenophane derivatives in which nucleobase and aromatic hydrocarbon (naphthalene or anthracene) moieties substituted to their cyclopentadienyl rings in a stacking mode between the two chromophores were synthesized, as a model system of intercalation of aromatic condensed-ring hydrocarbons to DNA. Characterization of the ferrocenophanes by spectrometriy and molecular modeling suggested that these chromophores interacted due to $\mathrm{NH}-\pi$ hydrogen bonding and $\pi-\pi$ charge transfer. A number of porphyrin derivatives covalently connected with a nucleobase or a nucleobase pair in a face-to-face mode between the porphyrin and nucleobase moiety were synthesized. The spectroscopic behavior of the derivatives indicate a greater affinity of the guanine-cytosine pair for porphyrin in comparison with the adenine-thymine pair. These results are compatible with the already reported spectroscopic and kinetic properties of mixing system of DNA and porphyrin derivatives. Moreover, the fluorescence spectra of the nucleobase-porphyrin derivatives gave a piece of evidence to cause DNA cleavage by photosensitizer via "type I" mechanism, in which direct action of singlet or triplet state of photosensitizer excited by laser irradiation brings about damage of cell or DNA.
\end{abstract}

Key words — nucleobase-porphyrin derivatives; photosensitized DNA cleavage mechanism; ferrocene-porphyrin derivatives; nucleobase-anthracene derivatives

\section{はじめに}

筆者は 1965 年に本薬学部に奉職して以来 90 年位 まで，有機金属錯体フェロセンの化学を中心に研究 を進めてきたが，それらについてはすでに総合論

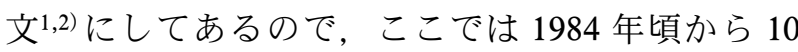
年ほどの間に手がけた生体機能関連分野の研究をま とめて記述することにしたい.

生体に関係する有機及び無機化学分野では, 例え ば酵素のような巨大分子の機能研究のために, 反応 の活性や相互作用が関与する局所的部分を機能的に 再現できるモデル系を構築し，低分子化合物におけ
るスペクトルや動力学的研究手法を用いて精密に解 析して，その時点では技術的に巨大分子のままでは 分からない知見を提供することが行われ，3,4)これら の手法はかなりの成功を収めてきた．特に 1973 年 の Collman ら5のの゚ケットフェンス・ポルフィリン は, 分子量 1000 程度の低分子量でありながら優れ たミオグロビン・モデルとしての機能を持ち，しか も鉄への酸素結合の状態を明らかにすることにも成 功し, 生体機能関連分野のその後の研究に多大な影 響を与えた。

我々はそれまで行ってきた芳香族性金属錯体フエ

本総説は, 平成 12 年度退官にあたり在職中の業績を中心に記述されたものである. 
ロセン類の研究を通して金属酵素と酸素分子の結 合，核酸に対して芳香環や金属が関与する系に興味 を持つようになり，フェロセンや種々の芳香環を building block としてそれらの生体機能をモデル化 することはできないかと考え，モデル系となりうる 化合物の分子設計を行うとともにそれらの合成研究 を開始した。

1. 積層型フェロセノポルフィリノファンの合成

フェロセンは低スピン 2 価の鉄を有するが, これ をポルフィリン錯体の面上に橋かけ構造によって固 定すれば，異種の電子構造を持つ金属が向き合う形 の複核錯体となる。 また，ポルフィリン平面の両側 から橋かけすれば鉄が上下に 3 個配列した三核錯体 になる，これらは，金属一金属間相互作用や電子移 動のモデル系になるかもしれない.さらに，フェロ センのシクロペンタジエニル環 (以後 $\mathrm{Cp}$ 環という) 平面とポルフィリン金属錯体平面が face-to-face と なるように橋かけすれば，芳香環を経由した金属一 金属間相互作用を調べるためのモデル系となる可能 性もある.これらの橋かけ鎖の長さを変えれば活性 点の間の様々な距離を持つ錯体が得られる. 当時, へム酵素の合成モデル系の研究が盛んに行われてお り, ${ }^{6-10)}$ 特に，複数の金属を含む金属酵素（例え ば，シトクローム酸化酵素など）や金属酵素間の電 子移動速度と金属間の距離の関係などが問題になつ ていたので, ${ }^{11)}$ フェロセン一ポルフィリン誘導体 は，それら金属酵素のモデル化合物として役立つと 考えられた。ささらには，それら橋かけ化合物はその 構造上電導性分子金属 ${ }^{12)}$ のような新しい材料として の期待も持たれた.

ポルフィリン部としては，5,10,15,20-tetrakis-(2aminophenyl) porphyrin $\left(\mathbf{1} ; \mathbf{M}=\mathrm{H}_{2}\right)$ の簡便な合成 法とアミノ基の方向によるアトロプ異性体の分離及 びその構造同定法が確立されていたので, ${ }^{5 b)}$ これを 利用した。 フェロセン部には 1,1'位及び 1,3- 位二 置換カルボン酸（2及び 3 $)^{13,14)}$ を用い，ポルフィリ ン部の 2 つのアミノ基とアミド結合により橋かけさ せることにした。種々のアミド合成法により 1 とフ エロセンカルボン酸の反応を検討したが，その中で 最も好い成績が得られたのは, $\mathrm{n}-\mathrm{Bu}_{3} \mathrm{~N}$ 存在下 2chloro-1-methylpyridinium iodide による方法15)であ つたので，おおむねこれを用いて合成した１のう ち 4 個のアミノ基の方向が互い違いになっている $5,10,15,20$-tetrakis- ( $\alpha, \beta, \alpha, \beta$-2-aminophenyl) porphy$\operatorname{rin}\left(\mathbf{1 A} ; \mathbf{M}=\mathrm{H}_{2}\right)$ と 1, $1^{\prime}$ - 置換カルボン酸（2）か らは二層構造（4） と三層構造（5）を持つ化合物が 得られた（Fig. 1).16）また， 1A と 1,3- 置換カルボ ン酸 (3) では二層構造の化合物 (6) は得られたが, 5 に対応する三層構造化合物は単離できなかった. 生成物中にクロマトグラフィ不能な難溶部分があ り，三層構造体はこの中に入っていると考えられる.

なお，得られたポルフィリン誘導体は，2つの芳 香族化合物を含む一種のファン類なので，それらの 命名法 ${ }^{17)}$ に従ってフェロセノポルフィリノファンと 呼ぶことにした。

これらの積層化合物のマススペクトルでは, 通常 のEI (electron impact) 法でイオン化しても分子イ オンは得られず，FD（field desorption）法による イオン化が必要であった. Table 1 に示したように,

${ }^{1} \mathrm{H}-$ 及び ${ }^{13} \mathrm{C}-\mathrm{NMR}$ スペクトルはその構造の特長を

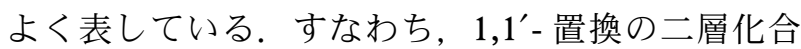
物（4）ではピロールプロトンが $\mathrm{AB}$ 系に分裂して $\mathrm{C}_{2 \mathrm{v}}$ 対称性を示し, $\mathrm{Cp}$ 環プロトンは真下にあるポ ルフィリンの反磁性効果を効果的に受けて, 対応す るカルボン酸に比べていずれも大きな高磁場シフト をしており, しかも側鎖の短い方がそのシフトは大 きい $(4 \mathrm{a}$ で $2.4-2.6 \mathrm{ppm}, 4 \mathrm{~b}$ で $2.1-2.3 \mathrm{ppm})$. 側 鎖メチレンプロトンも $\mathrm{Cp}$ 環に隣接する $\alpha$ 位は $\beta$ 位 に比べていずれも $0.75 \mathrm{ppm}$ 高磁場シフトする. $\mathrm{D}_{2 \mathrm{~d}}$ 対称構造の三層構造体（5）ではピロールプロトン はシングレットであらわれ，Cp 環プロトンは二層 体とほぼ同様な挙動で, 高磁場シフトは対応する 4 よりもわずかながら小さかった。また，1,3- 置換二 層体の橋かけ鎖が短い方の化合物（6a）では， $\mathrm{Cp}$ 環プロトンは 2 位が $3.8 \mathrm{ppm}$ の高磁場シフトする のに対して，4, 5 位の高磁場シフトは $1.1 \mathrm{ppm}$ であ り, 溶液中では $\mathrm{Cp}$ 環が 2 位部分をポルフィリン環 に接近するようにして大きく傾いたコンフォメーシ ヨンをとつていることが明らかとなった。 ところ が，橋かけ鎖が長くなつた化合物（6b）では，Cp 環プロトンは 2 位の高磁場シフトは $1.5 \mathrm{ppm}, 4,5$ 位の方は $4.0 \mathrm{ppm}$ となって $\mathbf{6 a}$ とは逆の挙動とな る。したがって， $6 \mathbf{b}$ の方は $\mathrm{Cp}$ 環が 4,5 位部分を 下に向くようにして傾いた配座をとっていることを 示した。しかも高磁場シフトは橋かけ鎖が長い方が 大きい。これら 1.3 置換体の配座を CPK モデルを 


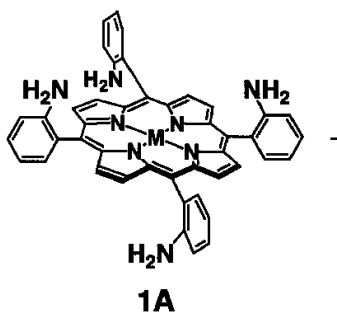

$+$

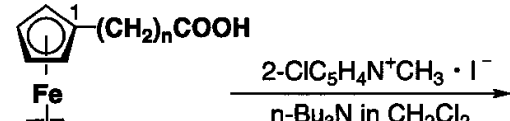

$\left(\mathrm{CH}_{2}\right)_{n} \mathrm{COOH}$

2

$$
\begin{aligned}
& \text { a: } n=2 \\
& \text { b: } n=3 \\
& \begin{aligned}
M=H_{2}, & F e(I I), \\
& \text { or } \mathrm{Fe}(\text { III)-Cl }
\end{aligned}
\end{aligned}
$$

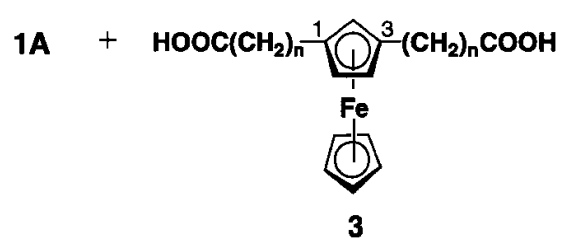

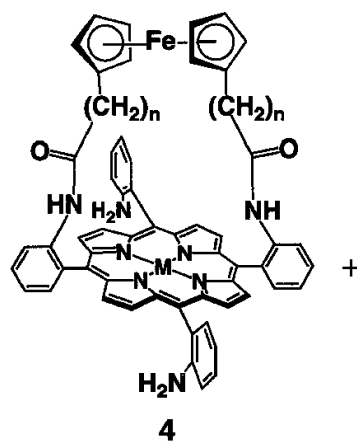

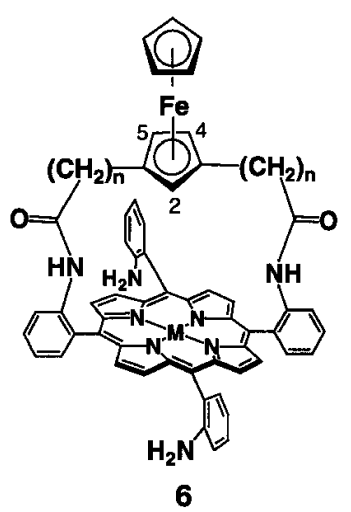

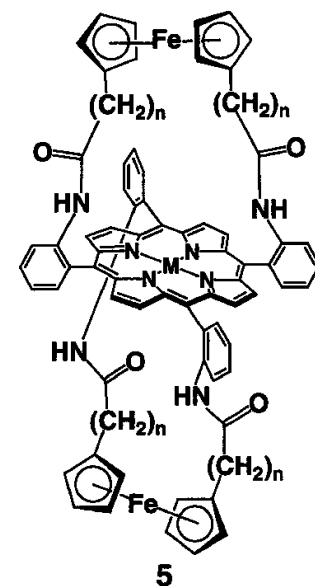

5

Fig. 1. Synthesis of Ferrocenoporphyrinophanes

使って考察してみると, 1,3 置換フェロセンはジメ チレン鎖で橋かけしたものはかなりひずみが大き く，トリメチレン鎖による橋かけ体の方が安定で, フェロセンがポルフィリン環に無理なく接近できる ことが分かった。しかし，なぜフェロセン部の傾き が逆の方向になるかは不明である。

次に，これらのポルフィリンの錯体化を行った. $\mathrm{DMF} /$ pyridine 中 $\mathrm{FeCl}_{2}$ で処理すると，いずれも $\mathrm{Fe}$ (III) - Cl 錯体が形成された。鉄が 3 価になるのは空 気酸化によるものである、錯体の生成は FD-MS と 吸収スペクトルにより確認した (Table 1)。4 をジ クロロメタン中 1-methylimidazol (Me-Im) 存在 下，アスコルビン酸で還元すると鮮やかな赤色の $\mathrm{Fe}(\mathrm{II})$ 錯体溶液となる。三層構造体 5 はポルフィリ ン環の上下に橋かけがあるので MeIm を配位子と する錯体は形成されないが，かわりにアンモニアを 加えると $\mathrm{Fe}$ (II) 錯体溶液となった。1,3-置換体の 場合はアスコルビン酸では還元されず， $\mathrm{NaBH}_{4}$ が 必要であった。これら $\mathrm{Fe}$ (II) 錯体に, 吸収スペク トルをモニターとしてジクロロメタン中 $-60^{\circ} \mathrm{C}$ で 酸素ガスを吹き込むと酸素錯体を形成したことを示 す吸収が現れた。 Fe (II) 酸素錯体の安定性は $5 \mathbf{b} 》$
$6 a>4 b>4 a \gg 5 a \geqq 6 b$ である. 1, $1^{\prime}$ 置換系の二層体 は橋かけ鎖の長さに応じて安定なのは当然と言えよ うが，三層体では鎖の長さで安定性が極端に異な り，また 1,3 置換系では鎖が長いほうが不安定とな つているのは興味深い。三層体の場合は鎖が短いと 第五配位子がうまく収まりきれないために不安定で,

1,3 系では非錯体の ${ }^{1} \mathrm{H}-\mathrm{NMR}$ で $\mathrm{Cp}$ 環は鎖が長いほ うがポルフィリン環に接近するという結果と関係が あるものとみられる。これら酸素錯体は $\mathbf{5 b}$ を除き やがてフェロセンの鉄が酸化されたことを示す緑色 溶液となっていく，しかし， $5 \mathbf{b}$ の $\mathrm{Fe}(\mathrm{II})$ 錯体のみ は形成された酸素錯体にアルゴンガスを吹き込むと 酸素が外れたもとの $\mathrm{Fe}(\mathrm{II})$ 錯体となる。この可逆 性は数回のターンオーバーに耐えた。 すなわち，こ の錯体は Collman がつくつたピケットフェンス・ ポルフィリン5) と同様にフェロセン橋かけ鎖を酸素 分子を収容する疎水性空間として用い，可逆的に酸 素を吸脱着する能力があることがわかった。なお，

$\mathrm{CPK}$ 模型によると $1,1^{\prime}$ - 系ではフェロセン鉄とポル フィリン鉄との距離は $n=2$ の場合（a 系列）で約 $0.6 \mathrm{~nm}, n=3$ (b 系列）で約 $0.7 \mathrm{~nm}$ である. 三層体 $5 \mathbf{b}$ の酸素錯体が安定なのは，両金属間が $0.7 \mathrm{~nm}$ 位 
Table 1. NMR and Electronic Absorption Spectral Data of Ferrocenoporphyrinophanes and Their Fe(III)-Cl Complexes, and Formation of $\mathrm{Fe}(\mathrm{II})$ Complexes

\begin{tabular}{|c|c|c|c|c|c|c|c|c|c|c|}
\hline \multirow{2}{*}{\multicolumn{2}{|c|}{ Compound }} & \multicolumn{5}{|c|}{ Ferrocenoporphyrinophane $\left(\mathrm{M}=\mathrm{H}_{2}\right)$} & \multirow{3}{*}{$\begin{array}{c}\mathrm{Fe}(\mathrm{III})-\mathrm{Cl} \\
\text { complexes } \\
\text { Absorption } \\
\text { bands }{ }^{c)} \\
(\mathrm{nm})\end{array}$} & \multicolumn{3}{|c|}{$\mathrm{Fe}$ (II) complexes } \\
\hline & & \multicolumn{3}{|c|}{$\left.{ }^{1} \mathrm{H}-\mathrm{NMR}^{a}\right)$} & \multicolumn{2}{|c|}{${ }^{13} \mathrm{C}-\mathrm{NMR}^{a)}$} & & \multirow{2}{*}{$\begin{array}{l}\text { Reduction } \\
\operatorname{agent}^{d)}\end{array}$} & \multirow{2}{*}{ Base } & \multirow{2}{*}{$\begin{array}{l}\text { Absorption } \\
\left.\text { band }{ }^{c, e}\right) \\
(\mathrm{nm})\end{array}$} \\
\hline no. & $n$ & $\mathrm{CH}_{2}{ }^{b)}$ & Cp-ring & Pyrrole & $\mathrm{CH}_{2}{ }^{b)}$ & Cp-ring & & & & \\
\hline $4 a$ & 2 & $\begin{array}{l}0.80(4 \mathrm{H}, \mathrm{m}) \\
1.55(4 \mathrm{H}, \mathrm{m})\end{array}$ & $\begin{array}{l}1.33(4 \mathrm{H}, \mathrm{m}) \\
1.64(4 \mathrm{H}, \mathrm{m})\end{array}$ & $\begin{array}{r}8.70 \& 8.88 \\
(\text { each } 4 \mathrm{H}, \mathrm{d})\end{array}$ & $\begin{array}{l}23.83 \\
38.55\end{array}$ & $\begin{array}{l}65.83 \\
66.86 \\
84.64\end{array}$ & $\begin{array}{l}418,513,586 \\
654,682\end{array}$ & $\mathrm{aa}^{f)}$ & 1-MeIm $\left.{ }^{g}\right)$ & 533 \\
\hline $4 \mathbf{b}$ & 3 & $\begin{array}{l}0.45(4 \mathrm{H}, \mathrm{m}) \\
1.10(4 \mathrm{H}, \mathrm{m}) \\
1.55(4 \mathrm{H}, \mathrm{m})\end{array}$ & $\begin{array}{l}1.68(4 \mathrm{H}, \mathrm{m}) \\
1.94(4 \mathrm{H}, \mathrm{m})\end{array}$ & $\begin{array}{l}8.76 \& 8.88 \\
(\text { each } 4 \mathrm{H}, \mathrm{d})\end{array}$ & $\begin{array}{l}25.45 \\
27.24 \\
37.22\end{array}$ & $\begin{array}{l}66.28 \\
66.87 \\
86.01\end{array}$ & $\begin{array}{l}418,512,582, \\
654,682\end{array}$ & aa & 1-MeIm & 536 \\
\hline 5a & 2 & $\begin{array}{l}0.90(4 \mathrm{H}, \mathrm{m}) \\
1.55(4 \mathrm{H}, \mathrm{m})\end{array}$ & $\begin{array}{l}1.53(4 \mathrm{H}, \mathrm{m}) \\
1.81(4 \mathrm{H}, \mathrm{m})\end{array}$ & $8.76(8 \mathrm{H}, \mathrm{s})$ & $\begin{array}{l}23.93 \\
38.84\end{array}$ & $\begin{array}{l}66.03 \\
67.00 \\
84.84\end{array}$ & $\begin{array}{l}421,513,580 \\
652,685\end{array}$ & aa & $\mathrm{NH}_{3}$ & 534 \\
\hline $5 \mathbf{b}$ & 3 & $\begin{array}{l}0.50(4 \mathrm{H}, \mathrm{m}) \\
1.10(4 \mathrm{H}, \mathrm{m}) \\
1.55(4 \mathrm{H}, \mathrm{m})\end{array}$ & $\begin{array}{l}1.81(4 \mathrm{H}, \mathrm{m}) \\
2.17(4 \mathrm{H}, \mathrm{m})\end{array}$ & $8.80(8 \mathrm{H}, \mathrm{s})$ & $\begin{array}{l}23.77 \\
27.47 \\
37.39\end{array}$ & $\begin{array}{l}66.52 \\
66.93 \\
86.24\end{array}$ & $\begin{array}{l}422,513,582, \\
656,681\end{array}$ & aa & 1-MeIm & 535 \\
\hline $6 \mathbf{a}$ & 2 & $\begin{array}{l}0.55(4 \mathrm{H}, \mathrm{m}) \\
1.25(4 \mathrm{H}, \mathrm{m})\end{array}$ & $\begin{array}{l}0.20(1 \mathrm{H}, \mathrm{t}) \\
2.90(2 \mathrm{H}, \mathrm{d}) \\
3.35(5 \mathrm{H}, \mathrm{s})\end{array}$ & $\begin{array}{r}8.75 \& 8.90 \\
(\text { each } 2 \mathrm{H}, \mathrm{d}) \\
8.78 \& 8.96 \\
(\text { each } 2 \mathrm{H}, \mathrm{d})\end{array}$ & $\begin{array}{l}24.60 \\
38.98\end{array}$ & $\begin{array}{l}65.17 \\
66.75 \\
68.46 \\
85.30\end{array}$ & $\begin{array}{l}420,515,583 \\
655,683\end{array}$ & $\mathrm{NaBH}_{4}$ & 1-MeIm & 543 \\
\hline $\mathbf{6 b}$ & 3 & $\begin{array}{l}0.27(4 \mathrm{H}, \mathrm{m}) \\
1.18(8 \mathrm{H}, \mathrm{m})\end{array}$ & $\begin{array}{r}-0.02(2 \mathrm{H}, \mathrm{d}) \\
2.46(1 \mathrm{H}, \mathrm{t}) \\
2.82(5 \mathrm{H}, \mathrm{s})\end{array}$ & $\begin{array}{c}8.75 \& 8.89 \\
(\text { each } 2 \mathrm{H}, \mathrm{d}) \\
8.81 \& 8.96 \\
(\text { each } 2 \mathrm{H}, \mathrm{d})\end{array}$ & $\begin{array}{l}24.42 \\
26.83 \\
36.40\end{array}$ & $\begin{array}{l}63.70 \\
66.46 \\
68.28 \\
85.19\end{array}$ & $\begin{array}{l}418,510,580 \\
652,680\end{array}$ & $\mathrm{NaBH}_{4}$ & 1-MeIm & 537 \\
\hline
\end{tabular}

a) In $\mathrm{CDCl}_{3}, \delta$ value. b) Methylene group combined with ferrocene moiety. c) In $\mathrm{CH}_{2} \mathrm{Cl}_{2} \quad d$ ) In $\mathrm{CH}_{2} \mathrm{Cl}_{2} / \mathrm{H}_{2} \mathrm{O}$ at room temperature. e) Only characteristic band is shown. $f$ ) Ascorbic acid. g) 1-Methylimidazole.

離れると酸素が入ってもフェロセン鉄の酸化が進行 しにくいとみられ，これは金属酸化のメカニズムに 関する興味深い結果である。 二層体が不安定なのは 酸素が橋かけの反対側に配位して $\mu$-オキソ二量体 が形成されるためではないかと考えている。

次に，ポルフリン金属上方の疎水性環境を高め た場合に，錯体の安定性に与える影響を調べるため に，橋かけ鎖がなくて空いている側に疎水性の壁 （フェンス）を立てた形の誘導体を合成した（Fig. 2). ${ }^{18)}$ ポルフィリン部としてすべてのアミノ基が同 じ方向を向いた 5,10,15,20-tetrakis- $(\alpha, \alpha, \alpha, \alpha$-2aminophenyl) -porphyrin（1B）を用いてフェロセン 誘導体とカップリング反応を行い, 次いで余ったア ミノ基にピバロイル基を結合させた. Figure 1 の化 合物の結果では 1,3 - 錯体以外は橋かけ鎖の長い方 が安定な錯体を形成するので, 7,8 は $n=3$ 及び 4 （b 及び $\mathbf{c}$ 系列）にしてある。 また， $8 \mathbf{b}$ 合成のカッ プリング反応の際に 10 も生成した.
これらの誘導体の構造についての詳細な説明は省 略するが，いずれもその対称性を反映した NMR ス ペクトルを示した。これらを $\mathrm{Fe}$ (III) - Cl, Fe (II), $\mathrm{Co}$ (III) - $\mathrm{Cl}$ 及び $\mathrm{Co}$ (II) 錯体に導き, 吸収スペクト ルによりそれらの挙動を調べた。その結果を要約す ると以下のようになる.

1） $7 \mathbf{b}$ と 10 の $\mathrm{Fe}(\mathrm{II})$ 錯体は酸素分子を可逆的に 吸脱着し，相当するフェンスのない錯体に 比べかなり安定な酸素錯体を形成する. 特 に 7b の $\mathrm{Fe}(\mathrm{II})$ 錯体ではわずかな酸素分圧で も酸素分子を取り込む.

2） Co (II) 錯体では，8b は酸素錯体を形成して 酸素分子を吸脱着し，7b は酸素錯体を形成 するが可逆性はなかった。

3） 1,3 置換体 9 の $\mathrm{Fe}$ (II) 錯体は酸素吸脱着を示 しフェンスがない場合よりは安定な酸素錯 体を形成したが，他のフェンス型錯体より も不安定であった。この場合, 酸素錯体に 


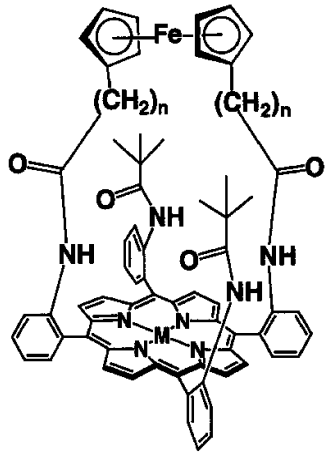

7

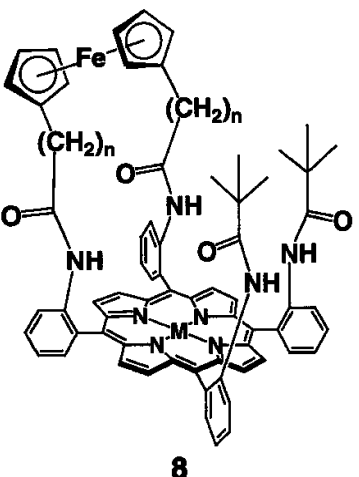

8

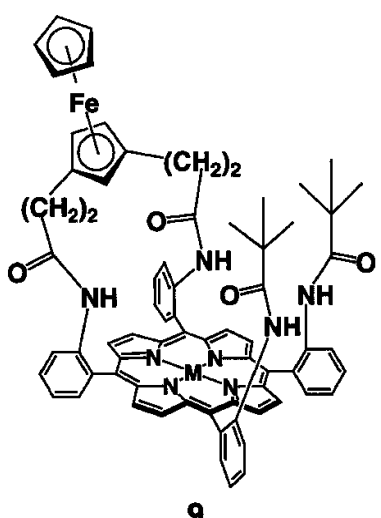

9

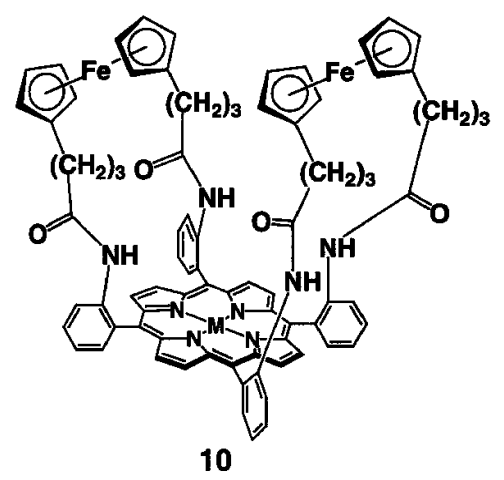

b: $\mathbf{n}=\mathbf{3}$

c: $n=4$

$\mathrm{M}=\mathrm{H}_{2}, \mathrm{Fe}$ (II), $\mathrm{Fe}(\mathrm{III})-\mathrm{Cl}$,

$\mathrm{Co}(\mathrm{II})$, or $\mathrm{Co}$ (III)-Cl

Fig. 2. Ferrocenoporphyrinophanes Having Picket-Fences

おけるフェロセン鉄の酸化は $\mathrm{Cp}$ 環を経由し ている可能性がある.

すなわち，ポルフィリン上方の疎水性を高めるこ とにより，錯体の安定性が大きくなることが示され た.

これらフェロセノポルフィリノファンは電子移動 又は電荷移動のモデル系として役立てるつもりであ つたが，吸収スペクトルではクロモフォアの吸収が 重なり合い電荷移動吸収帯の検出はならなかった.

また，当初予定していた電気化学的検討は溶液中の 安定性に問題があり行っていない.

2.フェロセンを合成部品として用いた核酸塩基 一縮合芳香環相互作用に関するモデル化合物の合成

DNA に対するインターカレーションは平面性を 有する $\pi$ 電子系ではかなり一般的で，とくにメチ ジウム ${ }^{19,20)}$ やアクリジン21-23)などの縮合複素多環 式化合物の例は有名である。このような多環縮合系 炭化水素でも行われることが示唆されていたが, Kumar ら ${ }^{24)}$ はアントラセンのような三環系縮合環 のインターカレーションの例を報告した. すなわち， DNA と9-anthrylmethylamine hydrochloride を混ぜ
て吸収スペクトルと蛍光スペクトルを測定し，アン トラセン部位が DNA二重らせんに挿入し，しか も，アデニンーチミン豊富な部分への特異性がある ことを推論した。DNAとの混合系における現象に 基づく推論であるが，その相互作用の本質が明らか になれば DNA 認識能に新たな知見を加えることが でき，興味ある展開が期待できるのではないかと思 われた。そこで，著者らはこの芳香環挿入部分のモ デル化系を低分子量の化合物で合成し，芳香環一核 酸塩基との相互作用についての詳細な知見を得るこ とを考えた.

ところで，フェロセンは 2 つの $\mathrm{Cp}$ 環が 0.332 $\mathrm{nm}$ の間隔で互いに平行になった構造を有してい る. 常温では 2 つ環が自由回転しているので, 各 環の置換基の位置関係を空間的に規定することはで きないが， Cp 環同士を橋かけしたフェロセノファ ンでは， $\mathrm{Cp}$ 環上の置換基間の関係を三次元的に制 御することができるようになり，橋かけの長さや位 置を変えることで微調整も可能となる。したがつ て，フェロセノファンの上下 $\mathrm{Cp}$ 環の適切な位置に 2 つのクロモフォアを有する置換基を導入すれば両 
クロモフォア間の相互作用を検討するための良いモ デル系になると考えられる，すなわち，フェロセノ ファンを合成部品（building block）として核酸塩 基と芳香環を結合させれば，両者の相互作用を検討 するには格好の形になる (Fig. 3).

そこで，分子模型を使って詳細に分子設計し（後 にモデリングにより確認した)，次のようなモデル 化合物を合成することにした。（i）フェロセン部は, $\mathrm{Cp}$ 環同士の自由回転を阻害した橋かけ体とし，橋 かけの長さを $3 \mathrm{C}$ 鎖と $4 \mathrm{C}$ 鎖の場合を合成してそれ らの違いを明らかにする。対照化合物として非橋か け体もつくる.（ii）芳香環としてはモデル反応と してナフタレンを用いて合成し，次にアントラセン 誘導体をつくる，ナフタレン誘導体は比較対照化合 物としても使える．芳香環とのリンカーは $\mathrm{Cp}$ 環と 同一平面を保つようにカルボニル基を用いる。（iii） 核酸塩基は Kumar ら ${ }^{24)}$ の結果から，とりあえずア デニン及びチミンを選ぶ。（iv）核酸塩基と $\mathrm{Cp}$ 環 をつなぐリンカーは，オキソジメチレン鎖とジメチ レン鎖の二種類をつくって比較する. ジメチレンを 用いるのは核酸塩基と芳香環の両クロモホアが最も 無理のない形式で接近して相互作用できる最適の空 間的配置を見つけることを意図したものである.

なお，フェロセンを building block とする分子認 識能を有する化合物の検討は，2,3 のグルー プ25-27)で行われている。しかし，彼らの発想と我 々の考えは独立のものであり，彼らは $\mathrm{Cp}$ 環同士の 自由回転を利用するが，我々の場合は橋かけにより 回転を阻害して，相互作用をより強力にするところ にねらいがある。

合成法と得られた化合物を Fig. 4 に要約して示 した。合成が達成された化合物はナフタレン系では

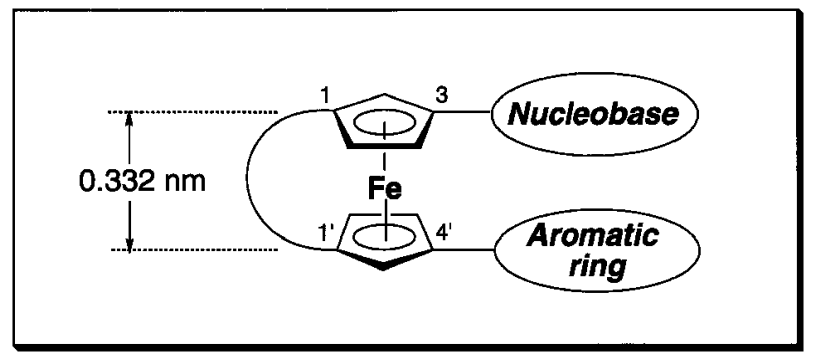

Fig. 3. A Schematic Presentation in Modeling of Ferrocenophane Derivative Combined with Both Nucleobase and Aromatic Ring in a Face-to-Face Mode 13a, 13b, 13c, 14，アントラセン系では 13a, 14 で， いずれもアデニン及びチミン誘導体である.

得られた化合物について ${ }^{1} \mathrm{H}-\mathrm{NMR}$ ，電子吸収又 ペクトルの測定，及び分子力学計算（パーソナル CAChe による MM 計算）を行い，次のような結果 を得た。

1）オキソジメチレン側鎖のナフタレン誘導体で は 13a, 13c, 13b の順，すなわち $\mathrm{Cp}$ 環の自由

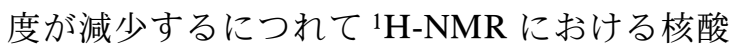
塩基プロトンの高磁場シフトが大きくなってお り，このシフトが芳香環の磁気異方性によるこ とを示すと共に，フェロセン核の構造特異性が 塩基と芳香環の空間的配置を規定することを明 らかにした。

2）ジメチレン側鎖のナフタレン誘導体（14）で は，対応するオキソジメチレン体に比べ塩基部 プロトンの高磁場シフトが大きい。したがつ て，ジメチレン側鎖は塩基部の空間的な自由度 を増大させ，塩基部を相互作用が最大になる様 式で芳香環に接近させているものと考えられる.

3） ジメチレン側鎖のチミン一アントラセン誘導 体（14-T）の ${ }^{1} \mathrm{H}-\mathrm{NMR}$ と MM 計算の結果は, チミンが芳香環に対し edge-to-face 型の配座を とって安定化していることを示した。これはチ ミンの 1 位 $\mathrm{NH}$ - 芳香環 $\pi$ 電子雲間の水素結合 によるものと見られる.

4） ジメチレン側鎖のアデニン一アントラセン誘 導体（14-A）では， ${ }^{1} \mathrm{H}-\mathrm{NMR}$ と MM 計算の結 果からアデニンが芳香環と face-to-face 型の配 座で安定化していることを示した。吸収スペク トルではアントラセン由来の吸収帯に顕著な淡 色効果（約 20\%）がみられ，クロモフォア間 に $\pi$ 一 スタッキングによる電荷移動相互作用 が働いているものと推定される.

以上の結果は，Kumar ら ${ }^{24)}$ が示したアデニン一 チミン対への芳香環の親和性がチミンの $\mathrm{NH}$ 水素 一 $\pi$ 電子間水素結合，アデニンの $\pi$ 一 $\pi$ 電荷移動相 互作用によることを示唆するものであった.

3. 核酸塩基一ポルフィリン誘導体の合成と性質 癌の光力学的診断及び治療メカニズム解明のモ デル系構築とその応用

ヘマトポルフィリン誘導体 (hematoporphyrin derivative, $\mathrm{HpD}$ ) を用いた癌の光力学的診断法 

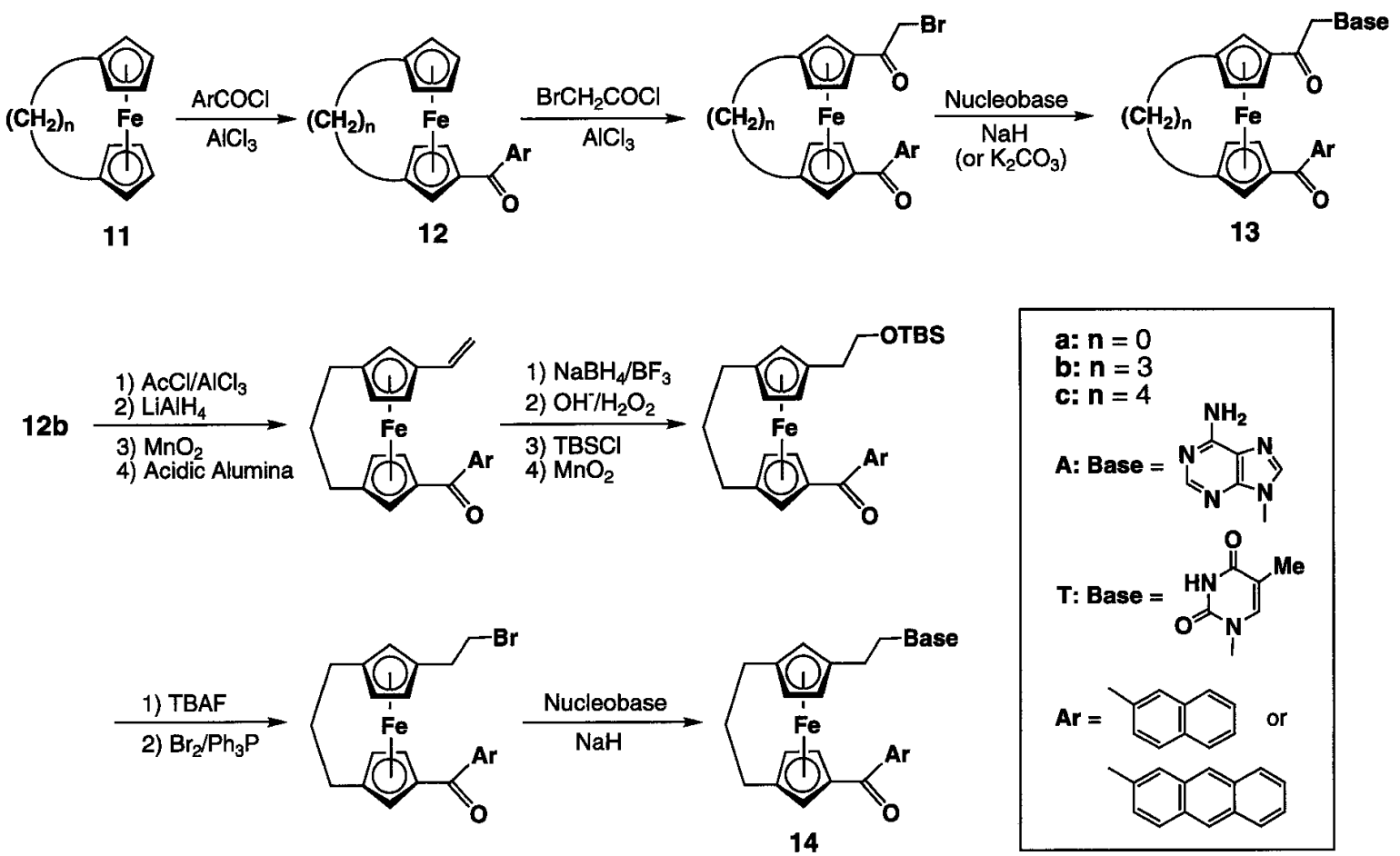

Fig. 4. Synthesis of Nucleobase-Ferrocenophane-Arene Derivatives

（photodynamic diagnosis, PDD）及び治療法（photodynamic therapy, PDT) ${ }^{28,29)}$ が我が国でも 1994 年 に承認され（一般名ポルフィマーナトリウム），主 として表在型初期癌の治療に用いられ良好な成績を おさめている.PDD と PDTが可能なのは，ポル フィリンが蛍光発光し，光増感作用を有することと 共に癌細胞に対し強い親和性を示すことによる。こ の癌細胞への親和性を，異常に早い細胞分裂で複製 を繰り返す DNA との強い相互作用としてとらえ， この立場で多くの生化学者がポルフィリン誘導体及 びその金属錯体と DNA との相互作用をスペクトル や動力学的手法を用いて検討し，両者が強い親和性 を有することを明らかにしている. ${ }^{30-38)}$ 例えば,

Fiel ら ${ }^{29)}$ は，ポルフィリン誘導体に牛胸腺 DNA を 加え, 溶液粘度の減少, Soret 帯 (400 nm 付近のポ ルフィリン特有の強い吸収帯) の吸光係数の減少, CD の誘起などを観測し，Pasternack ら ${ }^{38)}$ は左巻き らせん構造の Z-DNA にポルフィリン誘導体が共存 すると右巻きの B-DNA への巻き直しが起こること を見いだしている．また，一般にポルフィリンのポ リヌクレオチドに対する親和性は poly (dA-dT) よ りも poly (dG-dC) の方が強いことも示されている (Pasternack ら, ${ }^{31)}$ Marizilli ら $\left.{ }^{34)}\right)$ これらの結果か
ら，ポルフィリンが DNA にインターカレーション することは確実とされ，特にグアニンーシトシン対 リッチな部分に挿入しやすいと推定された.

しかしながら，これらの推論はいずれも DNA 又 はポリヌクレオチドと基質の混合物溶液のスペクト ルや物性から現象論的に導きだしたもので，必ずし も挿入部分の状況を分子論的に明らかにしたもので はなかった．また，巨大分子を扱うことに由来する 精密さの限界もあって，相互作用の本質に関わる局 所的な視点に欠けることは避けられなかった。

そこで我々は，はじめに述べたような巨大分子の 機能を低分子化合物でモデル化する手法を応用し， スペクトル法により精密に解析して相互作用の本質 を明らかにすることはできないかと考えた。

Pastermack ら ${ }^{31,38)}$ が主張するようにポルフィリン が塩基対間に挟まつた状態を仮定し，この挿入部分 を模式化すると Fig. 5 の左図のようになる．DNA への基質挿入部分を切り取った状況をできるだけ忠 実に再現するとすればポルフィリンと核酸の一単位 （リン酸一糖一塩基）を結合させた化合物となる. しかし，これには合成の難しさもあり，また単純な 系の方がむしろ相互作用の本質が明らかになる場合 もあることも考慮して，最初のモデル系には，核酸 


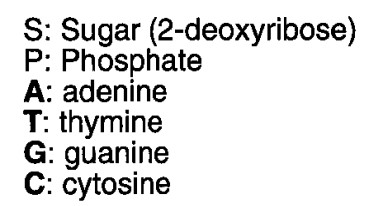

Porphyrin deriv.

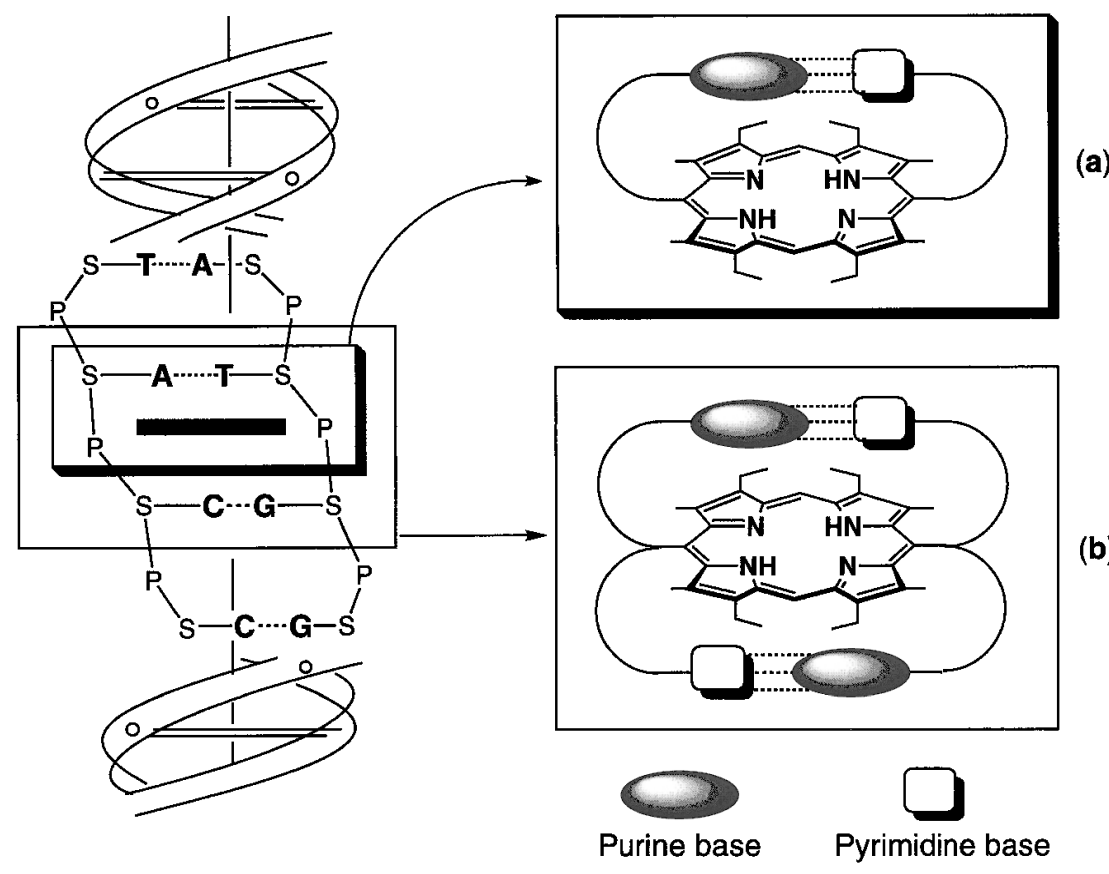

Fig. 5. Intercalation of a Porphyrin Derivative between the Base Pairs of DNA and Schematic Modelings of the Situation in the Intercalation

塩基対と芳香環の夕に着目し両クロモフォアの相互 作用を明らかにできる系を選んだ。すなわち，Fig. 5 の (a) で示したように, Watson-Crick 型で会合す る一対の相補塩基対がポルフィリン環平面と faceto-face で重なりあえるように設計された化合物の 構築を計画したのである.

それら単純な系を合成してその物性を調べて得ら れる情報は，インターカレーションそのものを再現 することにはならないにしても, 挿入の形態と要因 を分子論的に解釈するための基礎的なデー夕を与え るはずである，また，それらモデル系は化合物とし てもユニークな興味深い構造を持ち, 当初の目的以 外にも別な応用に供しうる可能性もある.

そのような観点にたって，次に示すように，とり あえずは DNA が有する 4 種の核酸塩基が結合した 化合物の合成から開始した。

3-1. アルキルアミド・リンカーによる核酸塩基 一ポルフィリン誘導体の合成ポルフィリン部と して 5,15-bis (2-aminophenyl) porphyrin（16 及び 17）を用いることにした。これにはアミノ基の方向 に基づくアンチ，シンのアトロプ異性体があるが, 単離と構造同定法はすでにChang ら ${ }^{39)}$ が確立して いた．分子模型の検討からアミド結合側鎖により核 酸塩基を結合させると, 目的の構造にするにはメチ
レン鎖は $n=3$ 又は 4 が適当であることがわかつ た。原料となる核酸塩基カルボン酸誘導体（15）は それまで知られていた核酸塩基の反応40-55) 組み 合わせて合成した.

ポルフィリン（16） とアデニン酪酸誘導体 （15-A）の反応では，アミド合成の常法の 1 つであ る $N, N^{\prime}$-dicyclohexylcarbodiimide (DCC) 処理法を 用いると少量の核酸塩基一ポルフィリン誘導体 (18) を与えた。しかし，この反応は i- $\mathrm{Pr}_{2} \mathrm{NEt} / \mathrm{Py} \cdot \mathrm{HCl}$ を共存 ${ }^{56)}$ させて carboethoxy chloride (CET-Cl) 又 は carbobenzyloxy chloride ( $\mathrm{CBZ}-\mathrm{Cl})$ を用いて反 応すると収率が格段に上がることがわかり, 以後基 本的にはこの反応剂を用い, 改良を加えながら縮合 を行った. Figure 6 に示したように，4 種すべての 核酸塩基についてアンチ型のモノ塩基誘導体を合成 した. ${ }^{57-59)}$

また，これらの手法を使ってアデニンとチミンを 段階的に結合させ，2つの塩基を有するアンチ体 $\mathbf{2 0}$ とシン体 21 を合成した（Fig. 7)。 シン異性体で は, 後述するように, アデニンとチミンが塩基対を 形成していることが ${ }^{1} \mathrm{H}-\mathrm{NMR} よ り$ 明らかにされ た. ${ }^{59)}$ グアニンーシトシン対を有する誘導体の合成 も試みられ，種々の反応を行ったが，アンチ，シン 体共にいずれも多数の生成物の混合物となり目的物 
B-H $\frac{\begin{array}{l}\text { 1) } \mathrm{NaOH}, \mathrm{NaH} \text { or } \mathrm{K}_{2} \mathrm{CO}_{3} \\ \mathrm{Br}\left(\mathrm{CH}_{2}\right)_{n} \mathrm{COOEEt}\end{array}}{\text { 3) aq } \mathrm{Ba}(\mathrm{OH})_{2} \text { or aq } \mathrm{HCl}}$ $\mathrm{B}-\left(\mathrm{CH}_{2}\right)_{n} \mathrm{COOH}$

15<smiles></smiles><smiles></smiles>
(T),<smiles>Cn1cnc2c(=O)[nH]c(N)nc21</smiles>
(G),<smiles>Cn1ccc(N)nc1=O</smiles>
(C),<smiles>COc1nccc(N)n1</smiles>

16: anti

17: syn
R. C.

(a), (b), or (c)

18: anti

19: syn

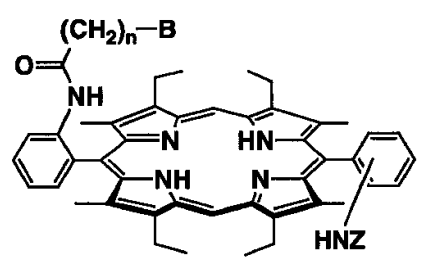

Fig. 6. Synthesis of Mononucleobase-Porphyrin Derivatives in Amide System

18a-A

$(\mathbf{z}=\mathrm{CBZ})$

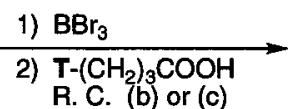

R. C. (b) or (c)

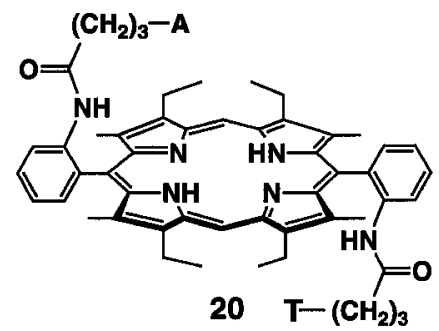

19a-A ( $\mathrm{Z}=\mathrm{CBZ}$ )

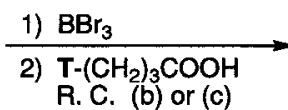

R. C. (b) or (c) a: $\mathbf{n}=3$

b: $n=4$

(a): $\mathrm{DCC} / \mathrm{Py} \cdot \mathrm{HCl}$

(b): $\mathrm{CET}-\mathrm{Cl} / \mathrm{Py} \cdot \mathrm{HCl} / \mathrm{i}-\mathrm{Pr}_{2} \mathrm{NEt}$

(c): $\mathrm{CBZ}-\mathrm{Cl} / \mathrm{Py} \cdot \mathrm{HCl} / \mathrm{i}-\mathrm{Pr}_{2} \mathrm{NEt}$

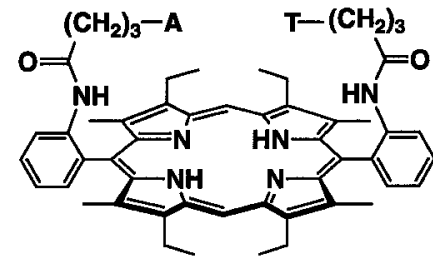

21

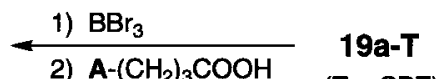

R. C. (b) or (c) ( $\quad(Z=C B Z)$

Fig. 7. Synthesis of Bisnucleobase-Porphyrin Derivatives in Amide System See Fig. 6 for R. C. (Reaction Conditions).

は単離できなかったので，グアニンーシトシン対誘 導体の合成は次に述べるエーテル・リンカーによる 合成法によって行った.

以上の誘導体のスペクトルは後でまとめて述べる.

3-2. アルキルエーテル・リンカーによる核酸塩 基一ポルフィリン誘導体の合成以上のアミド結 合誘導体の場合に 2 つの問題点が残された。 1 つは
カルボン酸とアミンの縮合反応がきれいに進まず, 副生物がかなり多くなり，したがって収率が全般的 に低いことである。モノ体を得るにはさしたる問題 はないが，相補塩基を有する誘導体を合成するのは 容易でなく，グアニン一シトシン誘導体が得られて いないのもそのためである.もう 1 つの問題点は, 核酸塩基とポルフィリンをつなぐ側鎖（リンカー） 
の根元にアミド結合があるために，側鎖に回転障害 を与えて塩基の向く方向を規制してしまう可能性が ある．また，アミドは極性が高く水素結合の相手と して働くので核酸塩基と相互作用するかもしれな い。これらの因子はいずれも取り除いた方がモデル 系として好ましいであろう。

そこで，合成法の改良と共にリンカーとなる側鎖 を低極性にするべくエーテル結合鎖で核酸塩基をつ なげたベンズアルデヒド（23）を用い，ジピリルメ タン誘導体（22）と直接ポルフィリン環形成反応を 行うことにした. ${ }^{60-62)}$

23 は，サリチルアルデヒドとジブロモアルカン を炭酸カリウムで反応させ, 得られたブロモ体と核 酸塩基を $\mathrm{NaH}$ 又は炭酸カリウムで処理して得られ た. ジピリルメタンとのカップリング反応を，一種 類の核酸塩基一ベンズアルデヒドを用い, $\mathrm{p}-\mathrm{TsOH}$ 又はトリクロロ酢酸で処理後 p- クロラニルで酸化 すると，対応するジ核酸塩基体のアンチ（25）とシ ン（26）が同時に得られる. これに非置換のベンズ アルデヒドを加えておくと, モノ塩基体（24）も生 成する．また，アデニン及びチミンの 2 種類のベン ズアルデヒドを共存させてジピリルメタンとカップ リング反応を行うと, 相補塩基対を有するアンチ体
（27-AT）とシン体（28-AT）が得られる（Fig. 8)。 グアニン，シトシン系でも同様に 27-GC と 28-GC が得られるが，グアニン相当部分を 2-amino-6chloropurine（以下クロロプリン）にしておいてカ ップリングさせ，その後塩酸で加水分解してグアニ ンに誘導した方が収率は良い．2 種の核酸塩基ベン ズアルデヒドのカップリング反応で, 塩基同士の水 素結合によりシン体の生成が優先することを期待し たが，実際はシンとアンチはほぼ $1 ： 1$ で生成し た。しかし，同一塩基の誘導体よりも相補塩基対を もつ誘導体の収率の方がかなり上回った.

これにより，必要なすべての組み合わせの核酸塩 基一ポルフィリン誘導体が得られ, 必要に応じ側鎖 の長さの異なる誘導体が自由に得られる合成法を確 立することができた，すべてではないがメチレン側 鎖の長さが $n=4,5,6$ の誘導体を合成し，その長さ とスペクトル挙動の関係を検討した。それらを亜鉛 錯体に導きメタル化の効果も調べた.

側鎖の方向によるアトロプ異性体のシン, アンチ

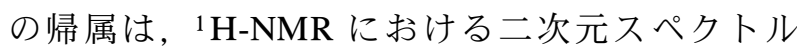
NOESY の解析により行った. また, 後述の九大佐 々木らとの共同研究で，核酸塩基類似体との会合を 調べる NMR 実験によりシン体の構造が支持され

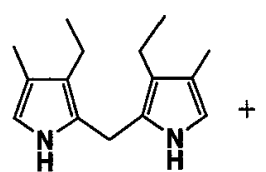

22

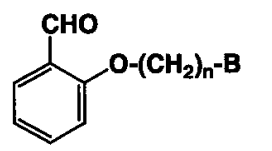

23

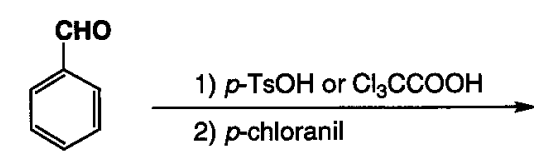

2) p-chloranil

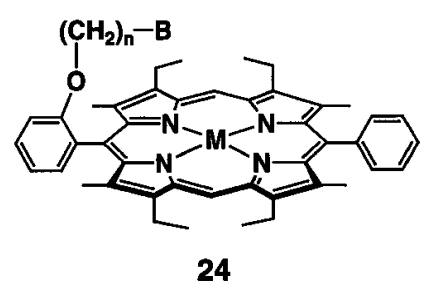

24

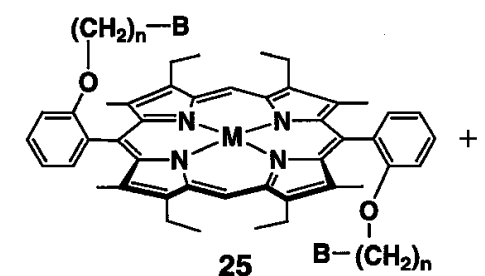

25

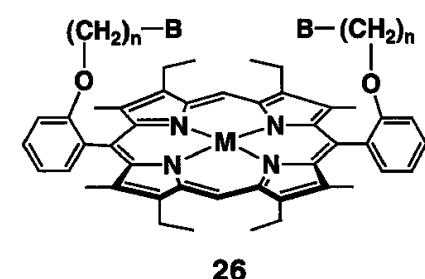

26

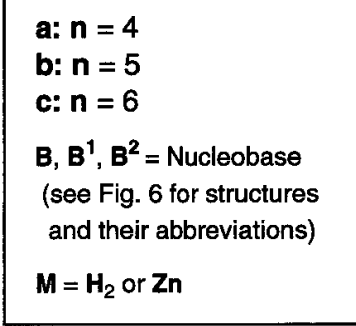

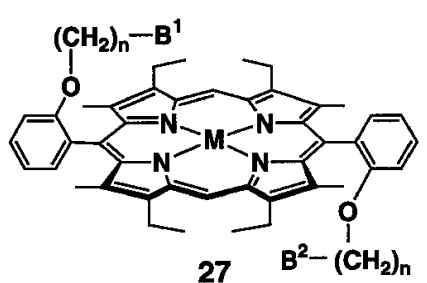

27

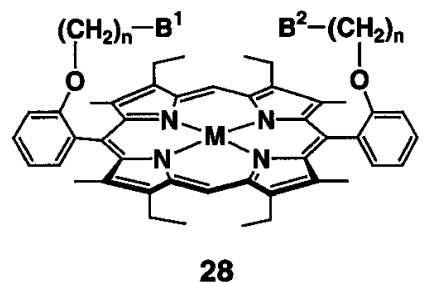

28

Fig. 8. Synthesis of Mononucleobase- and Bisnucleobase-Porphyrin Derivatives in Ether System 
た，さらに，詳細は省略するが，化学的に構造を確 定すべく別途ルートによる合成を試み，当初得た誘 導体の一部に誤りはあったが，ほとんどの誘導体の 構造帰属を支持する結果を得た. ${ }^{63)}$

なお，これらの化合物は分子構造上極めて興味深 い化合物なので，X-線結晶解析を行うべく単結晶 の作成を試み，考えられる結晶化の方法をすべて行 つてみたが薄片ができるのみで，測定可能な単結晶 は得られなかった。

このように Fig. 5 の（a)の第一世代ともいうべき モデル化合物の誘導体すべての組み合わせが得られ たので，核酸塩基相補塩基対がポルフィリンを上下 から挟んだ形の Fig. 5 の（b)に対応する第二世代の モデル系合成も行ってみた，核酸塩基は有機溶媒に 対し極めて溶解度が低いので，これが 4 個結合した 場合極端に溶解度が低下するはずである，スペクト ル測定に耐えるような溶解度を確保するには，長鎖 アルキル基を多数結合しておくのがよい，そこで， $n$-ヘキシル基をポルフィリンのピロール環に 4 本，フェニル基に 2 本結合させることにした。な お，第三世代としては水溶性の誘導体を目指してい たので，これに応用できることを考え，フェニル基 へのアルキル基導入はエーテル結合を介して行うこ とにした。この方法を確立しておけば，水溶性を高 めるポリエーテルをアルキル基のかわりに導入する のは容易になると考えたのである，具体的には Fig.
9 の化合物 $\mathbf{3 1}$ を目標とした.

31 の合成がかなり難しいことを予測し，まず試 験的にこれまでのモデル系にアルキル鎖を加えた 29 と 30 を合成してみてから，標的化合物に移るこ とにした，22 のエチル基をへキシル基に変えたジ ピリルメタンと， 23 のパラ位にへキシロキシ基を 導入した核酸塩基ベンズアルデヒド誘導体を合成 し，両者をポルフィリン形成反応に付した。 その結 果，29では 4 種の塩基誘導体，30 ではアンチ， シ ン共にグアニン及びシトシン誘導体を合成できた。 ベンズアルデヒド部分で $\mathbf{R}=\mathrm{OC}_{6} \mathrm{H}_{13}$ となる誘導体 の合成が難航し最終目的物はできていないが， $\mathbf{R}=$ $\mathrm{H}$ のビス核酸塩基一ベンズアルデヒド誘導体は得 られたので，これとテトラヘキシルジピリルメタン とのカップリングを行い， $31(\mathbf{R}=\mathrm{H}) \quad$ の $\mathbf{B}^{1}=\mathbf{B}^{2}=$ Cytosine 及び $\mathbf{B}^{\mathbf{1}}=$ Cytosine, $\mathbf{B}^{2}=$ Chloropurine 誘導 体は合成することができた. ${ }^{64,65)}$

3-3. 核酸塩基一ポルフィリン誘導体の分光学的

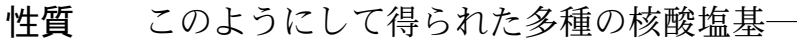
ポルフィリン誘導体は極めて興味ある NMR と吸収 スペクトルを与えたので，以下にまとめて記述する.

(a) ${ }^{1}$ H-NMR スペクトル 各誘導体の核酸塩 基プロトンの化学シフトを対応する塩基一アルキル 誘導体と比較したシフト差を Table 2 と 3 にまとめ て示した。 モノ塩基誘導体 $(\mathbf{1 8}, \mathbf{2 4})$ の ${ }^{1} \mathrm{H}-\mathrm{NMR}$ では，いずれの塩基プロトンもポルフィリン環の反

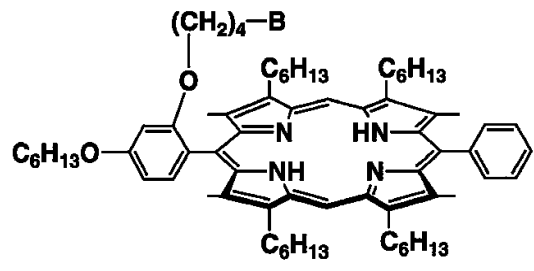

29

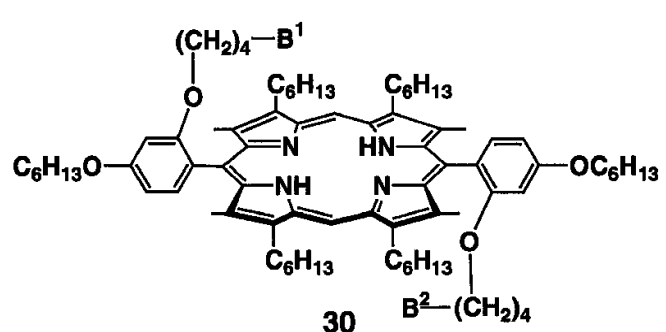

30

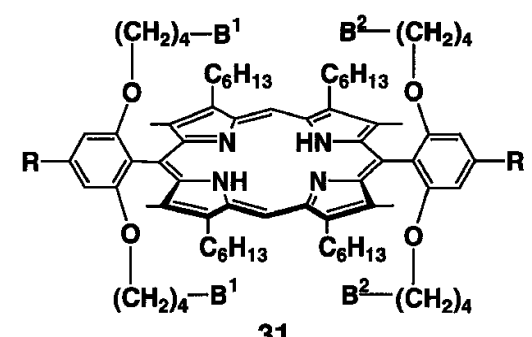

Fig. 9. Polyhexyl Nucleoside-Porphyrin Derivatives and Porphyrins Having Two Mucleobase Pairs 
Table 2. Chemical Shift Differences $(\Delta \delta)$ of the Base Proton Signals of Nucleobase-Porphyrin Derivatives in Amide System from Those of the Corresponding Reference Compound (Ethyl Ester of Nucleobasebutanoic Acid 15) in the ${ }^{1} \mathrm{H}-\mathrm{NMR} \mathrm{Spectra}$ in $\mathrm{CDCl}{ }^{a}$ )

\begin{tabular}{|c|c|c|c|c|c|c|c|c|c|c|c|c|c|}
\hline \multicolumn{3}{|c|}{ Compound } & \multicolumn{5}{|c|}{ Purine moiety } & \multicolumn{6}{|c|}{ Pyrimidine moiety } \\
\hline No. & $n$ & $\mathrm{Z}$ & $1-\mathrm{NH}$ & $2-\mathrm{H}$ & $8-\mathrm{H}$ & $-\mathrm{NH}_{2}$ & 9- $\mathrm{CH}_{2}$ & $3-\mathrm{NH}$ & $4-\mathrm{NH}_{2}$ & $5-\mathrm{CH}_{3}$ & $5-\mathrm{H}$ & $6-\mathrm{H}$ & $1-\mathrm{CH}_{2}$ \\
\hline 18a-A & 3 & CET & & -1.37 & -1.65 & -1.35 & -1.53 & & & & & & \\
\hline $18 \mathrm{~b}-\mathrm{A}$ & 4 & CET & & -0.78 & -0.41 & -0.38 & -0.97 & & & & & & \\
\hline 18a-A & 3 & $\mathrm{CBZ}$ & & -1.37 & -1.64 & -1.33 & -1.53 & & & & & & \\
\hline 18b-A & 4 & $\mathrm{CBZ}$ & & -0.78 & -0.40 & -0.38 & -0.97 & & & & & & \\
\hline 18a-A & 3 & $\mathrm{H}$ & & -1.39 & -1.63 & -1.36 & -1.53 & & & & & & \\
\hline $18 b-A$ & 4 & $\mathrm{H}$ & & -0.86 & -0.40 & -0.32 & -1.05 & & & & & & \\
\hline $18 a-T$ & 3 & CET & & & & & & -1.72 & & -0.73 & & -0.97 & -1.08 \\
\hline $18 \mathrm{~b}-\mathrm{T}$ & 4 & CET & & & & & & -1.05 & & -0.56 & & -1.21 & -1.06 \\
\hline $18 a-T$ & 3 & $\mathrm{CBZ}$ & & & & & & -1.72 & & -0.93 & & -1.19 & -1.21 \\
\hline $18 \mathrm{~b}-\mathrm{T}$ & 4 & $\mathrm{CBZ}$ & & & & & & -0.99 & & -0.58 & & -1.27 & -1.11 \\
\hline 20-AT & 3 & - & & -1.35 & -1.78 & b) & -1.50 & b) & & -0.66 & & -0.90 & -1.05 \\
\hline 18a-G & 3 & CBZ & -1.30 & & -3.67 & -0.22 & b) & & & & & & \\
\hline $18 b-G$ & 4 & $\mathrm{CBZ}$ & -0.11 & & -1.22 & -0.09 & -1.27 & & & & & & \\
\hline $18 a-C$ & 3 & $\mathrm{CBZ}$ & & & & & & & b) & & -3.59 & -2.17 & -0.82 \\
\hline $18 \mathrm{~b}-\mathrm{C}$ & 4 & CBZ & & & & & & & b) & & -2.58 & -2.27 & -1.23 \\
\hline $18 a-C^{\prime}$ & 3 & $\mathrm{CBZ}$ & & & & & & & -1.12 & & -0.81 & -0.69 & -0.66 \\
\hline
\end{tabular}

a) The spectra were measured in solutions of ca $0.9 \times 10^{-3} \mathrm{~mol} \mathrm{~m}^{-3}$. b) The chemical shift of the signal in $\mathrm{CDCl}_{3}$ has not been determined.

Table 3. Chemical Shift Differences $(\Delta \delta)$ of the Base Proton Signals of Nucleobase-Porphyrin Derivatives in Ether System from Those of the Corresponding Reference Compound (Nucleobase-Salicylaldehyde 23 ) in the ${ }^{1} \mathrm{H}-\mathrm{NMR}$ Spectra in $\mathrm{CDCl}_{3}{ }^{a}$

\begin{tabular}{|c|c|c|c|c|c|c|c|c|c|c|c|c|}
\hline \multicolumn{2}{|c|}{ Compound } & \multicolumn{5}{|c|}{ Purine moiety } & \multicolumn{6}{|c|}{ Pyrimidine moiety } \\
\hline No. & $n$ & $1-\mathrm{NH}$ & $2-\mathrm{H}$ & $8-\mathrm{H}$ & $\mathrm{NH}_{2}$ & 9- $\mathrm{CH}_{2}$ & $3-\mathrm{NH}$ & $4-\mathrm{NH}_{2}$ & $5-\mathrm{CH}_{3}$ & $5-\mathrm{H}$ & $6-\mathrm{H}$ & $1-\mathrm{CH}_{2}$ \\
\hline 24a-A & 4 & & -0.46 & -2.23 & -0.52 & -1.79 & & & & & & \\
\hline 24b-A & 5 & & -0.25 & -1.83 & -0.36 & & & & & & & \\
\hline $24 a-T$ & 4 & & & & & & -0.79 & & -1.94 & & -3.57 & -1.95 \\
\hline $24 a-G$ & 4 & -1.35 & & -1.11 & -0.72 & -1.73 & & & & & & \\
\hline $24 a-C$ & 4 & & & & & & & b) & & -6.33 & -4.85 & -1.73 \\
\hline 27-AT & 4 & & -0.08 & -1.64 & +1.51 & -1.14 & +4.75 & & -0.13 & & -0.92 & -1.35 \\
\hline 28-AT & 4 & & -0.45 & -2.09 & -0.57 & -1.72 & -0.77 & & -1.97 & & -3.59 & -2.12 \\
\hline 27-GC & 4 & +1.20 & & -1.45 & +0.76 & -1.56 & & b) & & -5.86 & -5.05 & -1.96 \\
\hline \multirow[t]{2}{*}{ 28-GC } & 4 & -0.17 & & -2.66 & -0.10 & -2.58 & & -6.49 & & -9.04 & -6.11 & -1.62 \\
\hline & & & & & +1.18 & -2.33 & & +0.23 & & & & -3.17 \\
\hline
\end{tabular}

a) The spectra were measured in solutions of ca $0.9 \times 10^{-3} \mathrm{~mol} \mathrm{~m}^{-3}$. b) The signal was not observed in $\mathrm{CDCl}_{3}$, possibly, due to broadening.

磁性異方性効果を受けて，アルキル体に比ベて大き く高磁場シフトし，期待通りに塩基プロトンがポル フィリン環の面上に位置していることを示した。こ の高磁場シフトは小さいもので $0.5 \mathrm{ppm}$, 大きいも のでは $6.3 \mathrm{ppm}$ (エーテル系のシトシン誘導体の 5-H）に達するものもある. しかも，メチレン鎖の 短い方が長い鎖の場合に比べ高磁場シフトが大き く，側鎖の長さがポルフィリン環との距離を規定し ており，両クロモフォアが層状に重なり合っている
（スタッキング）ことが明らかであった。また，核 酸塩基間で対応しているプロトンを比べてみると, プリン塩基ではグアニンの方がアデニンよりも高磁 場シフトが大きく，ピリミジン塩基ではシトシンの 方がチミンよりもシフトが大きい。そして，互いに 相補塩基対を形成する誘導体ではアデニン一チミン 対よりもグアニンーシトシン対の方が高磁場シフト が大きくなっており，したがって後者の方がポルフ イリン環に接近していることを示している。これは 
グアニンとシトシンにあるカルボニル基とポルフィ リン環内水素との強い水素結合が関係しているもの と推定された.

さらに，エーテル系で得られた相補塩基対を有す るアンチ誘導体（27）では，核酸塩基プロトンのう ち，炭素に結合するプロトンが高磁場シフトしてポ ルフィリン環の異方性効果を受けているのに対し, $\mathrm{NH}_{2}$ と $\mathrm{NH}$ プロトンがかなりの低磁場シフトして いるのが観測された。これは塩基間の水素結合の存 在を示し，アンチ型の構造から考えると分子間水素 結合により会合していると推定された（Fig. 10）.60) 一方，相補塩基を有するシン体（28）は， G-C, A-T 共にアンチ体よりも高磁場シフトが大きく, 2 つの塩基が分子内水素結合していてポルフィリン環 に接近していることを示した。 そして， G-C 対化 合物は A-T 対よりも明らかに高磁場シフトが大き く，シトシンの $5-\mathrm{H}$ は $9 \mathrm{ppm}$ ものシフトをするこ とが確認された。

（b）電子吸収スペクトル＼cjkstart各誘導体の電子吸 収スペクトルにおける Soret 帯（ポルフィリン特有 の $410 \mathrm{~nm}$ 付近の吸収帯）の吸収を Table 4 に示し た. Hypochromicity（淡色効果）は核酸塩基を持 たないポルフィリンの吸収強度との比較であり，こ

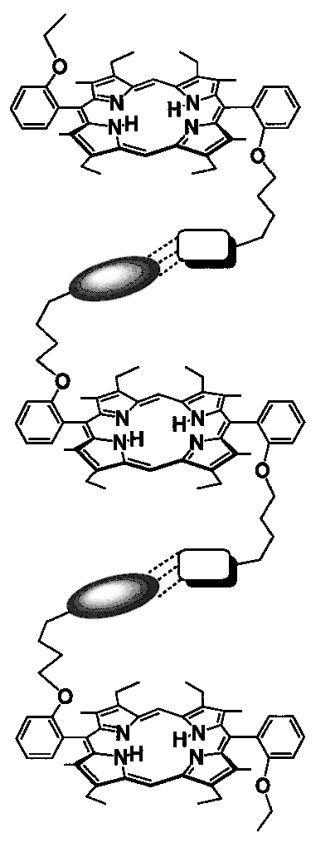

(a)
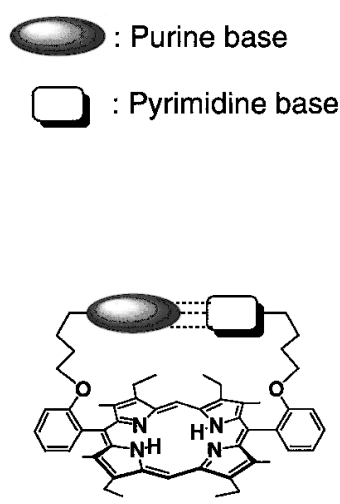

(b)
Fig. 10. Inter- and Intramolecular Base Pairing in anti (a) and syn (b) Bisnucleobase-Porphyrin Isomers, respectively
れが大きいほど，すなわち吸収強度の減少が著しい ほど両クロモフォアの相互作用が大きいことを意味 する。.いずれも淡色効果の傾向は ${ }^{1} \mathrm{H}-\mathrm{NMR}$ におけ る高磁場シフトの大きさとほぼパラレルであった. すなわち，モノ塩基誘導体 $(\mathbf{1 8}, \mathbf{2 4})$ の淡色効果は アデニン，チミンよりもグアニン，シトシンの方が 大きく，同じ塩基では側鎖の短い方が大きい。 ${ }^{1} \mathrm{H}-$ NMR で異常なシトシンの場合は淡色効果でも同様 で，シトシンではスタッキング・モードが独特な形 をとっていることを示唆した。 また，相補塩基対誘 導体ではシン体 $(21,28)$ の方がアンチ体 $(20,27)$ より淡色効果が大きくあらわれ，シン体の方がポル フィリン環と塩基が強く相互作用していることを示 し，NMR で推論された塩基間の分子内水素結合に よる環への接近を支持した（Fig. 10)。また，同様 にアンチ体の分子間水素結合しているという推論に

Table 4. Soret Band of the Porphyrin Ring in the Electronic Absorption Spectra of Nucleobase-Porphyrin Derivatives in $\mathrm{CH}_{2} \mathrm{Cl}_{2}$

\begin{tabular}{|c|c|c|c|c|c|}
\hline \multicolumn{3}{|c|}{ Compound } & \multirow{2}{*}{$\begin{array}{l}\lambda_{\max } \\
(\mathrm{nm})\end{array}$} & \multirow{2}{*}{$\begin{array}{c}\varepsilon \\
\left(\times 10^{5}\right)\end{array}$} & \multirow{2}{*}{$\begin{array}{c}\text { Hypochromicity } \\
(\%)\end{array}$} \\
\hline No. & $n$ & $\mathrm{Z}$ & & & \\
\hline \multicolumn{3}{|c|}{$\begin{array}{l}\text { Amide system Reference } \\
\left.\text { compound }^{a}\right)\end{array}$} & 408 & 2.12 & 0 \\
\hline 18a-A & 3 & CET & 410 & 1.75 & 17 \\
\hline $18 b-A$ & 4 & CET & 410 & 1.86 & 12 \\
\hline $18 a-T$ & 3 & CET & 408 & 1.73 & 18 \\
\hline $18 b-T$ & 4 & CET & 408 & 1.87 & 12 \\
\hline 18a-G & 3 & $\mathrm{CBZ}$ & 408 & 1.18 & 44 \\
\hline $18 \mathrm{~b}-\mathrm{G}$ & 4 & CBZ & 408 & 1.31 & 38 \\
\hline 18a-C & 3 & $\mathrm{CBZ}$ & 408 & 1.46 & 31 \\
\hline $18 b-C$ & 4 & $\mathrm{CBZ}$ & 408 & 1.37 & 35 \\
\hline 18a-C $\mathbf{C}^{\prime}$ & 3 & $\mathrm{CBZ}$ & 408 & 1.63 & 23 \\
\hline 20-AT (anti) & 3 & - & 411 & 1.65 & 22 \\
\hline 21-AT $(s y n)$ & 3 & - & 416 & 1.27 & 40 \\
\hline $\begin{array}{l}\text { Ether system } \mathrm{F} \\
\text { compound }^{b)}\end{array}$ & Refer & rence & 408 & 2.13 & 0 \\
\hline $24 a-A$ & 4 & & 409 & 1.84 & 14 \\
\hline $24 b-A$ & 5 & & 409 & 2.02 & 5 \\
\hline $24 a-T$ & 4 & & 408 & 1.99 & 7 \\
\hline 24a-G & 4 & & 410 & 1.18 & 45 \\
\hline $24 a-C$ & 4 & & 409 & 1.90 & 11 \\
\hline 27-AT (anti) & 4 & & 410 & 1.67 & 22 \\
\hline 28-AT $(s y n)$ & 4 & & 410 & 1.37 & 36 \\
\hline 27-GC & 4 & & 411 & 1.31 & 38 \\
\hline 28-GC & 4 & & 409 & 1.11 & 48 \\
\hline
\end{tabular}

a) 5,15-Bis (2-amino) phenyl-2, 8, 12, 18-tetraethyl-3, 7, 13, 17-tetramethylporphyrin.

b) 5,15-Bis (2-propoxy) phenyl-2, 8, 12, 18-tetraethyl-3, 7, 13, 17-tetramethylporphyrin. 
も矛盾しない.

長鎖アルキル基を有する 29-31 のスペクトル挙動 は他の誘導体と細かい点で多少異なるが, 本質的な 違いはない。

以上の分光学的挙動は，すでに述べたポルフィリ ン誘導体は poly (dA-dT) よりも poly $(\mathrm{dG}-\mathrm{dC})$ の 方に親和性が高いという Pasternack ら ${ }^{31)}$ や Marzilli ら ${ }^{34)}$ の報告と全く一致するもので，モデル系による ミクロな分子論的見地からも支持されることが確認 された.

各誘導体の亜鉛錯体もスペクトルを測定し た. ${ }^{66,67)}$ 優れた規則性は得られなかったが，核酸塩 基が亜鉛に配位していて, 必ずしも両クロモホアが 平行にスタッキングしていないことを示唆する結果 を得ている。 Pasternack ら ${ }^{31)}$ は金属錯体の DNA 相互作用も調べていて, 軸配位子が入るような金属 (Zn, Co, Fe など) 錯体では DNA 相互作用の形式 が異なるとしているが，上の結果はこれを裏付ける ものと考えられる.

以上のように，DNA にインターカレーターが挿 入した場合の一部分を切り出し, この形をもとに設 計した誘導体が，DNA やポリヌクレオチドを使っ て得られた分光学的挙動をよく反映し, 期待通りに 巨大分子の機能発現におけるモデル系として役立つ ことが示された。

\section{3-4. 核酸塩基一ポルフィリン誘導体の応用}

これらの化合物はその構造の特異性のゆえにポルフ イリン又は核酸が関係する生体機能関連の研究分野 の研究に利用され，重要な知見を提供する可能性を 持つ、種々の検討を行つたが，そのうちまとまりの ある結果についてのみ記述する.

（a）核酸塩基認識能 モノ核酸塩基誘導体で は，その塩基部分はポルフィリン環の真上にあるこ とが明らかとなったので，もしその溶液に相補塩基 を加えると水素結合により会合するであろう。そし て, 添加物の方もポルフィリンの反磁性異方性効果 を受けて高磁場シフトするので，それを検出するこ とにより誘導体の核酸塩基認識能を示すことができ る.そこで，モノアデニン誘導体の重クロロホルム 溶液にチミンカルボン酸エステルを加えて ${ }^{1} \mathrm{H}$ NMR を測定した. ${ }^{57)}$ その結果，アデニンのアミノ 基及びチミンの NH プロトンの低磁場シフト（各 々, $+0.52,+2.20 \mathrm{ppm})$ と共に, チミンの 5- メチ
ル基と 6-H プロトンの高磁場シフト（各々， $-0.11,-0.23 \mathrm{ppm}$ ）が観測された。 すなわち，両 塩基の間に強い水素結合が形成され，それによりチ ミンの方もポルフィリン環上におかれることになつ て反磁性異方性を受けたものと推定される。 また, 基質濃度を薄くするか, チミン/アデニンの比を大 きくするとシフトは小さくなり, 塩基一ポルフィリ ンをつなぐ鎖が長くなつてもシフトが減少する。こ のように，水素結合形成による会合で相手の塩基を 認識していることが明らかとなった。 チミン一ポル フィリン誘導体にアデニンカルボン酸エステルを加 えても全く同様な挙動が観測された。 また，グアニ ン及びシトシン誘導体でもほぼ同様であったが, シ グナルが重なり合っていて帰属が明らかになってい ない個所がある。

（b）核酸塩基対と会合能を有する人工核酸塩基 の結合様式を検証 ヒト遺伝子の解明が終わり病 原塩基配列が明らかになるとその治療法を確立する ためには標的塩基を認識して切断できる方法をデザ インする必要がある。この 1 つの手段として考えら れているのは, DNA の標的塩基配列近隣に選択的 に巻きついて三重らせん（triplex）を形成するよう な人工塩基の開発で，これを利用し何らかの処理を することで望みの部分を切断することができる．そ のような研究が Dervan ら 68,69) を中心に展開されて いる.

佐々木らは選択的に塩基対を認識する人工系の化 合物を合成する研究を行っており, DNA の G-C 対 の major groove 側を選択的に認識して triplex を形 成しうる人工核酸塩基（Fig. 11）をモデリングに よりデザインし合成した。この人工塩基が実際に triplex を形成するかどうかを検出するのに, G-C 対の形成が確証されているシン誘導体（28-GC）は 最適の構造をしている. そこで, 彼らが合成した化 合物 32 と 28a-GC を共に重 DMSO に溶かして ${ }^{1} \mathrm{H}-$ NMR で NOESY が測定したところ, 両者が triplex 複合体を形成すると接近するはずのプロトン同士に

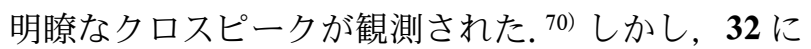
A-T 対のシン誘導体 28a-AT を加えてもこのような 相関は見られず, 彼らの化合物が確かに G-C 対を 選択的に認識して triplex を形成することを確認す ることができた。 また，これらの結果によって，我 々の化合物のシン, アンチのアトロプ異性体の構造 

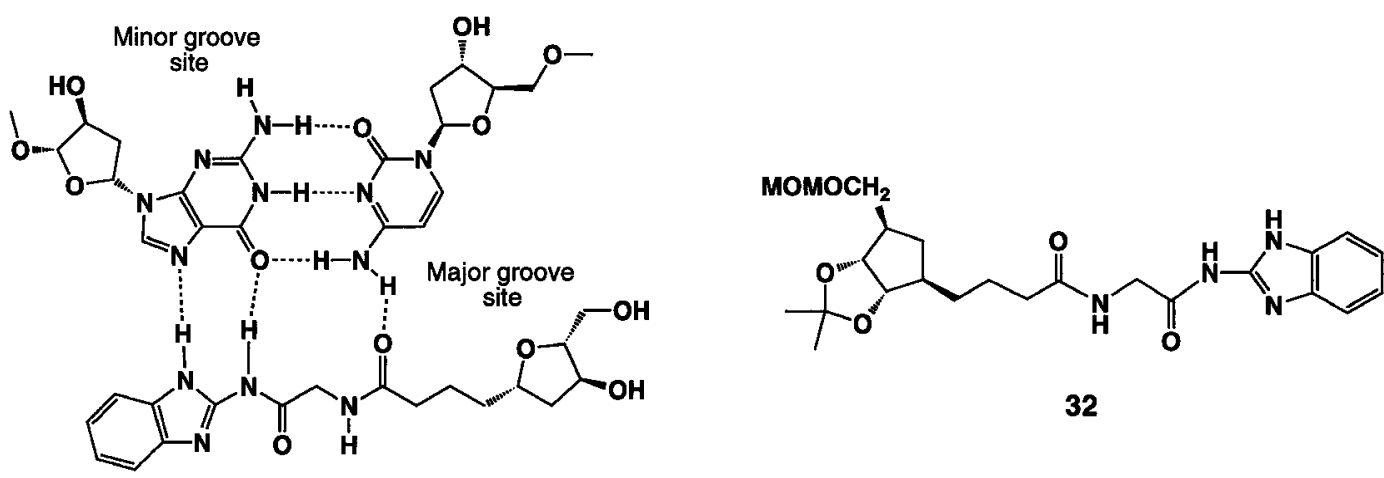

32

Fig. 11. Design of Artificial Nucleobases to Form a Triple Complex with Guanine-Cytosine Pair and the Designed Compound (32) Employed in NOESY Experiment together with 28a-GC

帰属も支持される結果となつた。

(c) 光化学的核酸破壊のメカニズム解明のため のモデル系この項目の最初にも述べたが，この 研究のきっかけは, 癌の光力学的診断と治療で光増 感剤として使われるポルフィリンの役割と癌細胞破 壊のメカニズムを解明するためのモデル系構築にあ った．現在光増感剤として使われているへマトポル フィリン誘導体は動物由来のへムから製造されてい るが, 副作用の低下やレーザー感受性の向上などを 実現するために，これに変わる光増感剤の開発が多 くの研究者によってなされている. ${ }^{71)}$ 小林，小宮山 $ら^{72}$ は水溶性と安全性の観点から植物由来のクロロ フィル誘導体の 1 つ Na pheophorbide (Na-Phde) 及び微生物由来の zincphyrin に着目して検討し, 優れた抗腫瘍活性を有することを見いだした（Fig. 12)。さらに，それら光増感剤を使って腫瘍細胞破 壊のメカニズムの解明も行っていた.

ところで, 光増感剤による腫瘍細胞破壊のメカニ ズムとして 2 つのタプが考えられている. ${ }^{73)}$ 簡単 に説明すると（Fig. 13），光増感剤は光を吸収して 励起一重項になるが，この一部は系間交差（intersystem crossing, I.S.C.) によって励起三重項にな る. 寿命は一重項より三重項の方がはるかに長い. 一重項のラジカル又はイオンラジカルが直接 DNA 又は細胞に損傷を与えるというのが Type I のメカ ニズムであり，三重項から溶存酸素（三重項酸素， $\left.{ }^{3} \mathrm{O}_{2}\right)$ へのエネルギー移動により一重項酸素 $\left({ }^{1} \mathrm{O}_{2}\right)$ が生成しこれが生体組織と反応して障害を与えるの が Type II の機構である. 寿命の関係から多くの場 合 Type II で反応が進行するので，HpD でもこの

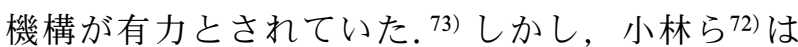

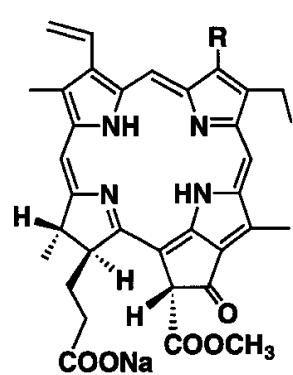

Pheophobide

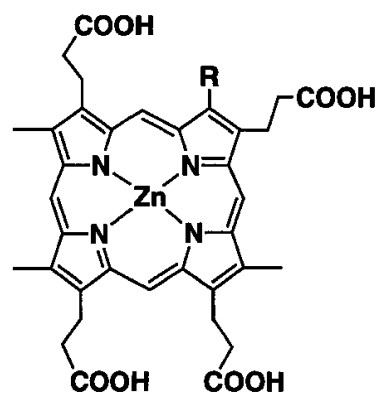

Zincphyrin
Fig. 12. Novel Sensitizers for Photocleavage of DNA

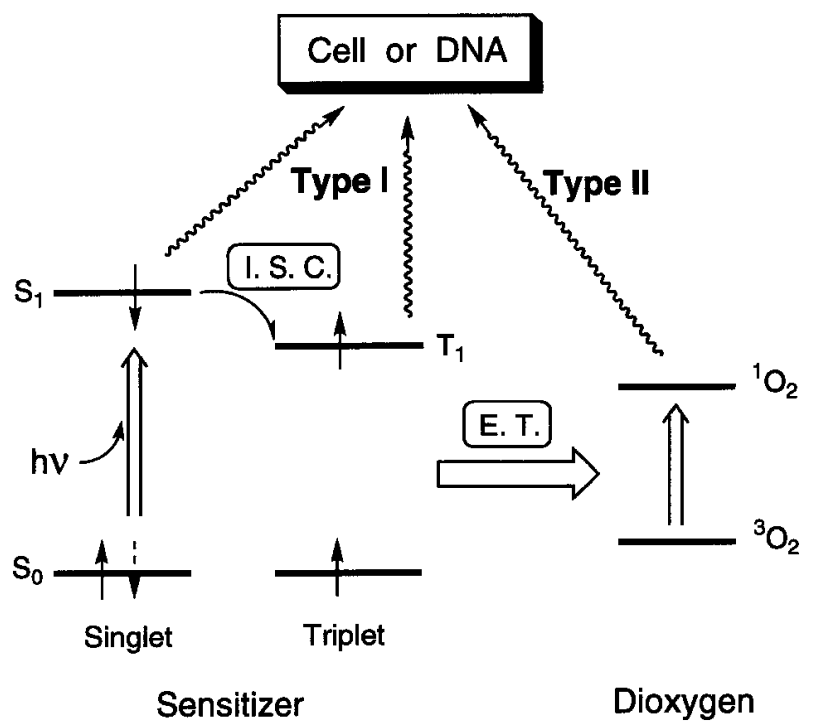

Fig. 13. Proposed Mechanisms for Photodamage of Cell or DNA by Photosensitizer

Na-Phde 及び類縁化合物の亜鉛錯体（zincphyrin） が嫌気性条件で効率良くDNA 切断を起し, 酸素存 在下の光照射でも一重項酸素発生は全くないか，あ 
つてもわずかであることが確認された.

これらのことから，小林らはNa-Phde と zincphyrin が Type I を経由して DNA 破壊を行つ ている可能性が高いとして, Na-Phde と 4 種の核 酸塩基の酸化電位を測定して比較した（Fig. 14）. その結果，光増感剤の一重項は，ピリミジン塩基 (シトシン，チミン)を直接酸化することはないが, プリン塩基（グアニン，アデニン）からは極めて効 率良く電子を引き抜き得ることが明らかになった。

しかし，これは電気化学的な証拠であって光増感 でそれが起る直接的証拠にはならない，核酸塩基と ポルフィリンが face-to-face で向き合っている化合 物 24, 28 を分光学的に検討すればその直接の証拠 を与えることができる，そこで，まず 4 種のモノ核 酸塩基一ポルフィリン誘導体（24a）及びその亜鉛 錯体の蛍光スペクトルを測定した. ${ }^{74-76) ~}$ 核酸塩基 を持たない対照化合物のスペクトルと共に，1つの チャートにまとめて Fig. 15 に示してある。これを 見ると明らかなように，チミンとシトシン誘導体で はほとんど消光されないが，アデニンとグアニン誘 導体には強い消光がみとめられ，しかもその程度は グアニンの方が大きい，亜鉛錯体でもチミン誘導体 で消光がやや強まることを除けばほとんど同じであ った．消光の程度はすでに述べた吸収スペクトルの 淡色効果の大きさとパラレルであり, 酸化電位の挙
動とも全く一致するものであつた.

これら一連の結果より次のことが推論される。核 酸塩基の近隣に増感剂があり，増感剂が励起される と直ちに酸化電位の低いプリン塩基から一電子移動 が起り，したがってプリン塩基はカチオンラジカル となるが，これが引き金になって連鎖的にDNAの 分解反応が起る。 すなわち，ポルフィリン系の増感 剂による腫瘍細胞破壊は Type I のメカニズムで進 行することを強く支持する結果となった.

さらに，これらのことを確かなものとするため に，我々の得ているほかの誘導体 $(24 a, 24 b, 27,28)$ についても蛍光スペクトルを測定した. ${ }^{76)}$ スペクト ルはあげないが，その結果を要約すると以下のよう にまとめられる.

1）核酸塩基とポルフィリンをつなぐ側鎖を長く するほど蛍光の消光は減少し, 核酸塩基が消光 の要因であることが確認された.

2）相補塩基対を有するシン体ではプリン塩基単 独の誘導体より消光は減少し，ピリミジン塩基 との対形成により酸化電位は上昇するという予 想と一致した。

なお，これらの測定中，核酸塩基一ポルフィリン 誘導体の光感受性に関するいくつかの興味ある現象 も見つかっている，例えば，蛍光スペクトルは高希 釈条件で測定するので溶液はほとんど無色である

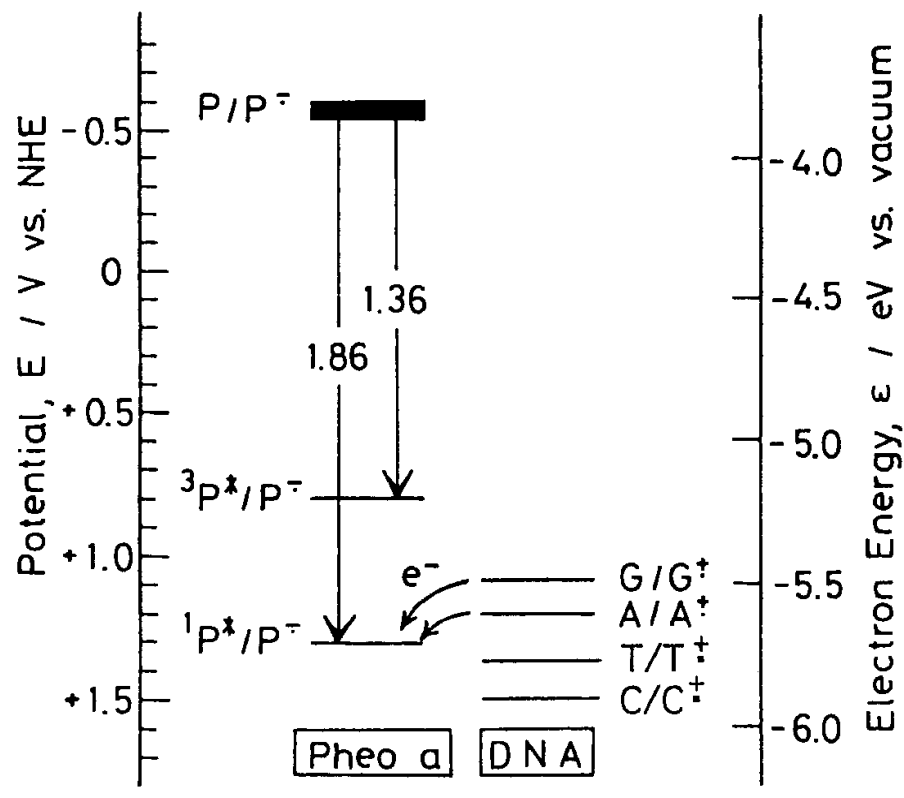

Fig. 14. Ground- and Excited-State Reduction Potentials and the Singlet and Triplet Excitation Energies of Phephobide in DMF, and Oxidation Potentials of Adenine (A), Guanine (G), Thymine (T), and Cytosine (C) 


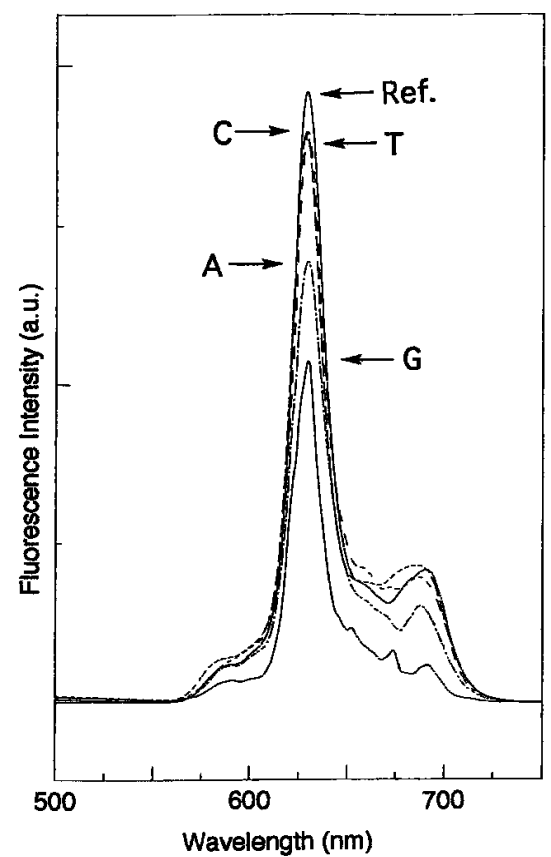

(a)

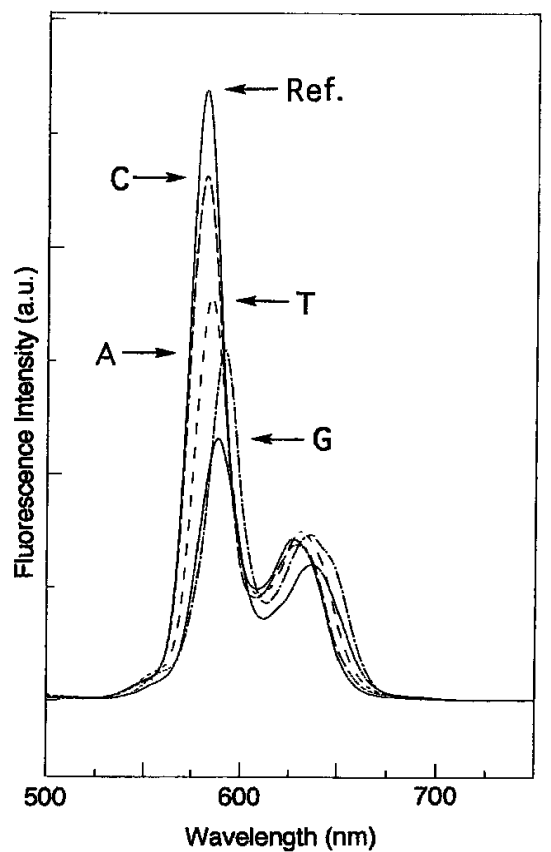

(b)

Fig. 15. Fluorescence Spectra of Adenine (A), Guanine (G), Thymine (T), and Cytosine (C) Derivatives of Porphyrin (24a, $\mathbf{M}=$

$\left.\mathrm{H}_{2}\right)$ (a) and the Corresponding Zinc Complexes $(\mathbf{2 4 a}, \mathbf{M}=\mathrm{Zn}) \quad(\mathbf{b})$

Reference compounds (Ref.) in (a) and (b) are 5,15-Bis (2-propoxy) phenyl-2,8,12,18-tetraethyl-3,7,13,17-tetramethylporphyrin and its zinc complex, respectively.

が，クセノンランプの光照射により蛍光測定した後 は淡黄緑色に変化し，これの吸収スペクトルには新 たな吸収（440 nm）が出現する。ところがこれは 経時的に退色し，無色となつた溶液はもとの吸収ス ペクトルに戻る，すなわち，これら誘導体は光照射 により可逆的に変化する。 このとき生成する化学種 は電荷移動錯体，ラジカルイオン対などの可能性が あり，これを解明することで増感剤と核酸塩基の光 反応に重要な知見を与える可能性がある.

\section{おわりに}

最初にも書いたように，東京理科大学薬学部在職 中の前半はサンドイッチ型の独特な構造を有する有 機金属錯体フェロセンに魅せられ，種々の誘導体の 反応，合成，スペクトル，構造解析などの研究を通 して，電子状態や反応に対する金属関与のメカニズ ムや部分的な構造変化が分子全体の構造と反応性に 及ぼす効果の規則性などを明らかにしてきた. ${ }^{1,2}$ 薬 学部にあってこれらの錯体化学と構造有機化学的な 研究を進めるうち，そこで得られる知見や手法を生 体関連の検討に役立てることはできないかと考え て，本論文で記したような研究を開始したのは
1984 年頃のことである．以来 10 年程の間に研究の 土台が確立され方向性が明確になり予期以上の成果 が現れ始めた。ところが 95 年になって，本薬学部 の研究室構成の再編が行われ，諸事情により著者は 情報薬学研究室の立ち上げに参加することになった ため,これらの研究は完成をみることなく中止を余 儀なくされた．研究全体が，特にはじめに述べた 2 つの項目が中途半端な形で終わっているのはそのた めと理解していただきたい。しかし，物性研究やモ デル系としての検討が十分に行われなかったとはい え，合成されたそれぞれの化合物は大変ユニークな 構造を有しており，種々の応用や発展性をもつもの と考えられ，そのきっかけにでもなればと考え，こ の稿を記した次第である。なお，最近 5 年間の情報 薬学研究室における「抗炎症作用を有する薬物及び 植物成分の活性と構造の相関に関する研究」はいず れ稿を改めてまとめたいと考えている.

謝辞本研究ではその性質上，目的は合成その ものにはなく得られた化合物のキャラクタリゼーシ ヨンにある。したがって，合成の記述にはほとんど 
紙面を割いていないが，実際には研究の大方の時間 は合成に費やしている．そのような多くの困難を伴 つた実験の担い手として頑張ってくれた共同研究者 の高野進一, 岡田達典, 丸山典昭, 岸端就介, 池田 幸一，宮崎和城，松田尚明，丸山勝 (いずれも修士) の諸君に深い感謝の意を表したい。また，項目 3(4) - (b) 及び 3- (4) - (c) は，それぞれ，九州大学薬学 部佐々木茂貴助教授及び東京大学工学部小林正美博 士（現筑波大学物質工学系助教授）との共同研究に よるものである.これらの研究は我々の化合物の有 用性を示すことができたものとして特筆すべきもの である．お二人の方々に心より感謝申し上げたい.

\section{REFERENCES}

1) Hisatome M., Yamakawa K., J. Synth. Org. Chem. Japan, 48, 319-330 (1990) .

2) Hisatome M., Rev. Heteroatom Chem., 6, 142 -176 (1992).

3) Tabushi I., Tetrahedron, 40, 269-292 (1984).

4) Dugas H., "Bioorganic Chemistry, A Chemical Approach to Enzyme Action," SpringerVerlag, New York, 1989.

5) a) Collman J. P., Gagne R. R., Halbert T. R., Marchon J.-C., Reed C. A., J. Am. Chem. Soc., 95, 7868-7870 (1973); b) Collman J. P., Gagne R. R., Reed C. A., Halbert T. R., Lang G., Robinson W. T., ibid., 97, 1427-1439 (1975).

6) Ogoshi H., Sugimoto S., Yoshida Z., Tetrahedron Lett., 1977, 169-173.

7) a) Collman J. P., Denisevich P., Konai Y., Marrocco M., Koval C., Anson F. C., J. Am. Chem. Soc., 102, 6027-6032 (1980); b) ColIman J. P., Chong A. O., Jameson G. B., Oakley R. T., Rose E., Schmittou E. R., Ibers J. A., J. Am. Chem. Soc., 103, 516-533 (1981).

8) Gunter M. J., Mander L. N., McLaughlin G. M., Murray K. S., Berry K. J., Clark P. E., Buckingham D. A., J. Am. Chem. Soc., 102, 1470-1473 (1980).

9) Schauer C. K., Akabori K., Elliott C. M., Anderson O. P., J. Am. Chem. Soc., 106, 11271128 (1984).

10) Eaton S. S., Eaton G. R., Chang C. K., J. Am. Chem. Soc., 107, 3177-3184 (1985).
11) a) McGourty J. L., Blough N. V., Hoffman B. M., J. Am. Chem. Soc., 105, 4470-4472 (1983); b) Peterson-Kennedy S. E., McGourty J. L., Hoffman B. M., J. Am. Chem. Soc., 106, 5010-5012 (1984); c) Baum R. M., Chem. \& Eng. News, 1984, Dec. 24, pp. 2427.

12) Hoffman B. M., Ibers J. A., Acc. Chem. Res., 16, 15-21 (1983).

13) Graham P. J., Lindsey R. V., Parshall G. W., Peterson M. L., Whiteman G. M., J. Am. Chem. Soc., 79, 3416-3420 (1957).

14) Hisatome M., Tachikawa O., Sasho M., Yamakawa K., J. Organomet. Chem., 217, C17-C20 (1981).

15) Bald E., Saigo K., Mukaiyama T., Chem. Lett., 1975, 1163-1167.

16) Hisatome M., Takano S., Yamakawa K., Tetrahedron Lett., 26, 2347-2350 (1985) .

17) a) Smith R. H., "Bridged Aromatic Compounds," Academic Press, New York, 1964; b) Keehn P. M., Rosenfeld S. M. (eds.), "Cyclophanes," Academic Press, New York, 1983.

18) a) Hisatome M., Okada T., Kato J., Yamakawa K., Abstracts of papers, the 107th Annual Meeting of the Pharmaceutical Society of Japan, Kyoto, April 1987, p. 279; b) Hisatome M., Okada T., Yamakawa K., Abstracts of papers, The 12th International Symposium on Macrocyclic Chemistry, Hiroshima, July 1987, p. 197; c) Hisatome M., Okada T., Yamakawa K., Abstracts of papers, the 108th Annual Meeting of the Pharmaceutical Society of Japan, Hiroshima, April 1988, p. 78.

19) Herzberg R. P., Dervan P. B., Biochemistry, 23, 3934-3945 (1984).

20) Fromherz P., Rieger B., J. Am. Chem. Soc., 108, 5361-5362 (1986).

21) Bowler B. E., Hollis L. S., Lippard S. J., J. Am. Chem. Soc., 106, 6102-6104 (1984).

22) Zimmerman S. C., Lamberson C. R., Cory M., Fairley T. A., J. Ame. Chem. Soc., 111, 6805-6809 (1989).

23) Slama-Schwok A., Teulade-Fichou M.-P., Vigneron J.-P., Taillandier E., Lehn J.-M., $J$. Ame. Chem. Soc., 117, 6822-6830 (1995).

24) a) Kumar C. V., Asuncion E. H., J. Chem. Soc., Chem. Commun., 1992, 470-472; b) Ku- 
mar C. V., Asuncion E. H., J. Am. Chem. Soc., 115, 8547-8553 (1993).

25) Medina J. C., Li C., Bott S. G., Atwood J. L., Gokel G. W., J. Am. Chem. Soc., 113, 366367 (1991).

26) Constable E. C., Angew. Chem. Int. Ed. Engl., 30, 407-408 (1993).

27) Guther R., Nieger M., Vogtle F., Angew. Chem. Int. Ed. Engl., 32, 601-603 (1993).

28) Review: Bonnet R., Chem. Soc. Rev., 24, 1933 (1995), and references cited therein.

29) Fiel R. J., Howard J. C., Mark E. H., DattaGupta N., Nucleic Acids Res., 6, 3093-3118 (1979)

30) Review: Marzilli L. G., New J. Chem., 14, 409 -420 (1990), and references cited therein.

31) Pasternack R. F., Gibbs E. J., Villafranca J. J., Biochemistry, 22, 2406-2414 (1983) .

32) Ward B., Skorobogaty A., Dabrowiak J. C., Biochemistry, 25, 7827-7833 (1986).

33) Sari M. A., Battioni J. P., Dupre D., Mansuy D., Le Pecq J. B., Biochemistry, 29, 42054215 (1990).

34) Marzilli L. G., Pettho G., Lin M., Kim M. S., Dixon D. W., J. Am. Chem. Soc., 114, 75757577 (1992).

35) Pastenack R. F., Bustamante C., Collings P. J., Giannetto A., Gibbs E. J., J. Am. Chem. Soc., 115, 5393-5399 (1993).

36) Petho G., Elliott N. B., Kim M. S., Lin M., Dixon D. W., Marzilli L. G., J. Chem. Soc., Chem. Commun., 1993, 1547-1548.

37) Kuroda R., Tanaka H., J. Chem. Soc., Chem. Commun., 1994, 1575-1576.

38) McKinnie R. E., Choi J. D., Bell J. W., Gibbs E. J., Pasternack R. F., J. Inorg. Biochem., 32, 207-224 (1988).

39) Young R., Chang C. K., J. Am. Chem. Soc., 107, 898-909 (1985).

40) a) Leonard N. J., Scott T. G., Huang P. C., J. Am. Chem. Soc., 89, 7137-7138 (1967); (b) Browne D. T., Eisinger J., Leonard N. J., J. Am. Chem. Soc., 90, 7302-7323 (1968).

41) Kim M., Gokel G. W., J. Chem. Soc., Chem. Commun., 1987, 1686-1688.

42) Platzer N., Galons H., Bensald Y., Miocque M., Bram G., Tetrahedron, 43, 2101-2108 (1987)

43) Wolfe M. S., Borcherding D. R., Borchardt R.
T., Tetrahedron Lett., 30, 1453-1456 (1989).

44) Huryn D. M., Sluboski B. C., Tam S. Y., Tadaro L. J., Weigele M., Tetrahedron Lett., 30, 6259-6262 (1989).

45) Kim Y. H., Kim J. Y., Lee C. H., Chem. Lett., 1988, 1045-1048.

46) Phadtare S., Zemlicka J., J. Org. Chem., 54, 3675-3679 (1989).

47) Norbeck D. W., Spanton S., Broder S., Mitsuya H., Tetrahedron Lett., 30, 6263-6266 (1989).

48) Uenishi J., Takahashi K., Motoyama M., Akashi H., Chem. Lett., 1993, 255-256.

49) Dezor-Mazur M., Koraniak H., Langer J. J., Golankiewicz K., J. Chem. Soc., Perkin Trans. 2, 1989, 1209-1212.

50) Nollet A. J. H., Huting C. M., Pandit U. K., Tetrahedron, 25, 5971-5981 (1969).

51) Harnden M. R., Jarvest R. L., Tetrahedron Lett., 26, 4265-4268 (1985).

52) Kjellberg J., Johansson N. G., Tetrahedron Lett., 27, 6541-6544 (1986).

53) Harnden M. R., Jarvest R. L., Bacon T. H., Boyd M. R., J. Med. Chem., 30, 1636-1642 (1987)

54) Halazy S., Ehrhard A., Danzin C., J. Am. Chem. Soc., 113, 315-317 (1991).

55) Lee W. W., Martinez A. P., Goodman L., Henry D. W., J. Org. Chem., 37, 2923-2927 (1972)

56) Wieland T., Faesel J., Faulstich H., Liebigs Ann, Chem., 713, 201-208 (1968).

57) Hisatome M., Maruyama N., Furutera T., Ishikawa T., Yamakawa K., Chem. Lett., 1990, 2251-2254.

58) Hisatome M., Maruyama N., Ikeda K., Yamakawa K., Heterocycles, 36, 441-444 (1993)

59) Hisatome M., Maruyama N., Ikeda K., Furutera T., Ishikawa T., Yamakawa K., Chem. Pharm. Bull., 44, 1801-1811 (1996).

60) Hisatome M., Ikeda K., Kishibata S., Yamakawa K., Chem. Lett., 1993, 1357-1360.

61) Hisatome M., Maruyama M., Ikeda K., Yamakawa K., Abstracts of papers, the 66th Annual Meeting of Chemical Society of Japan, Nishinomiya, September 1993, p. 87.

62) Hisatome M., Maruyama M., Taguchi S., Yamakawa K., Abstracts of papers, the 115th 
Annual Meeting of the Pharmaceutical Society of Japan, Sendai, March 1995, No. 2, p. 102.

63) Hisatome M., Abe T., Tatsuta D., Abstracts of papers, the 117th Annual Meeting of the Pharmaceutical Society of Japan, Machida, March 1997, No. 2, p. 44.

64) Hisatome M., Matsuda M., Ikeda K., Yamakawa K., Abstracts of papers, the 66th Annual Meeting of Chemical Society of Japan, Nishinomiya, September 1993, p. 87.

65) Hisatome M., Matsuda M., Maruyama M., Ikeda K., Yamakawa K., Abstracts of papers, the 37th Annual Meeting of Kanto Branch, the Pharmaceutical Society of Japan, Tokyo, November 1993, p. 95.

66) Hisatome M., Maruyama M., Ikeda K., Yamakawa K., Abstracts of papers, the 114th Annual Meeting of the Pharmaceutical Society of Japan, Tokyo, March 1994, No. 2, p. 124.

67) a) Hisatome M., Maruyama M., Yamakawa K., Abstracts of papers, the 68th Annual Meeting of Chemical Society of Japan, Nagoya, October 1994, p. 287; b) Hisatome M., Matsuda M., Maruyama M., Yamakawa K., ibid., p. 287.

68) a) Griffin L. C., Kiessling L. L., Beal P. A., Gillespie P., Dervan P. B., J. Am. Chem. Soc., 114, 7976-7982 (1992); b) Mrksich M., Dervan P. B., ibid., 115, 2572-2576 (1993) ; c) Colocci N., Distefano M. D., Dervan P. B., ibid., 115, 4468-4473 (1993); d) Mrksich M., Dervan P. B., ibid., 115, 9892-9899 (1993); e) Dwyer T. J., Geierstanger B. H., Mrksich M., Dervan P. B., Wemmer D. E., ibid., 115, 9900 -9906 (1993) ; f) Hunziker J., Priestley E. S., Brunar H., Dervan P. B., ibid., 117, 26612662 (1995).
69) Zimmerman S.C., Schmitt P., J. Am. Chem. Soc., 117, 10769-10770 (1995).

70) Sasaki S., Nakashima S., Nagatsugi F., Tanaka Y., Hisatome M., Maeda M., Tetrahedron Lett., 36, 9521-9524 (1995).

71) Bonnett R., Chem. Soc. Rev., 24, 19-33 (1995).

72) a) Komiyama M., Kobayashi M., Harada M., Chem. Lett., 1991, 2123-2126; b) Kobayashi M., Koyama S., Nakazato M., Miyoshi N., Wolff C., Daikuzono N., Tanielian C., Sasaki M., Komiyama M., J. Clinic., Laser Med. Surg., 12, 133-138 (1994); c) Kobayashi M., Koyama S., Miyoshi N., Yokotsuka D., Watanabe M., Wolff C., Tanielian C., Toriya M., Sasaki M., Komiyama M., Photomed. Photobiol., 16, 65-69 (1994).

73) Praseuth D., Graudemer A., Verlhac J.-B., Kraljic I., Sissoeff I., Guillee E., Photochem. Photobiol., 44, 717-724 (1986).

74) Kobayashi M., Matsuda M., Kise H., Hisatome M., Photomed. Photobiol., 17, 117-119 (1995).

75) Kobayashi M., Kise H., Tanielian C., Wolff C., Toriya M., Nakazato M., Sasaki M., Matsuda M., Hisatome M., "Food Factors for Cancer Prevention,', Springer-Verlag, Tokyo, 1997, pp. 572-576.

76) a) Hisatome M., Matsuda M., Yamakawa K., Kobayashi M., Abstracts of papers, the 115th Annual Meeting of the Pharmaceutical Society of Japan, Sendai, March 1995, No. 2, p. 102; b) Hisatome M., Matsuda M., Maruyama M., Kobayashi M., Abstracts of papers, the 10th Symposium on Biofunctional Chemistry, Kyoto, May 1995, pp. 61-63. 